\title{
UK guidelines on the management of variceal haemorrhage in cirrhotic patients
}

\author{
R Jalan, P C Hayes
}

\subsection{Introduction}

These guidelines on the management of variceal haemorrhage were commissioned by the British Society of Gastroenterology under the auspices of the Liver Section. They were written in June 1998 and have been corrected and agreed upon by the members of the Liver Section. The nature of variceal haemorrhage in cirrhotic patients with its complex range of complications makes rigid guidelines inappropriate.

Over the past few years there have been numerous advances in the management of variceal haemorrhage in patients with cirrhosis. These have included better endoscopic techniques with the widespread availability of video endoscopy, establishment of variceal band ligation, availability of newer drugs such as somatostatin and vasopressin analogues, better surgical techniques, and finally the availability of transjugular intrahepatic portosystemic stent shunt (TIPSS).

These guidelines deal specifically with the
Department of

Internal Medicine,

Royal Infirmary of

Edinburgh, Lauriston

Place, Edinburgh

EH3 9YW, UK

R Jalan†

P C Hayes

†Present address: Institute of Hepatology, RFUCLMS, 69-75 Chenies Mews, London WC1E 6HY, UK

Correspondence to: Dr R Jalan. Email: rjalan@ucl.ac.uk management of varices in patients with cirrhosis and are not designed to address: (1) the management of the underlying liver disease; (2) the management of variceal haemorrhage in children; or (3) variceal haemorrhage from other aetiological conditions.

\subsection{Validity and grading of recommendations}

These guidelines have been produced to conform to the system proposed by the North of England evidence based guidelines development project. ${ }^{12}$
Table 1 Strength of recommendations

\begin{tabular}{|c|c|c|c|}
\hline & $\begin{array}{l}\text { A } \\
\text { (the group feels this } \\
\text { element of care should } \\
\text { be strongly } \\
\text { recommended) }\end{array}$ & $\begin{array}{l}\text { B } \\
\text { (a recommendation } \\
\text { rated moderately } \\
\text { important by the } \\
\text { group) }\end{array}$ & $\begin{array}{l}\text { C } \\
\text { (rated as relatively } \\
\text { unimportant by the } \\
\text { group, although may } \\
\text { be considered in some } \\
\text { cases) }\end{array}$ \\
\hline $\begin{array}{l}\text { I } \\
\text { (well designed RCTs, } \\
\text { meta-analyses, or } \\
\text { systematic reviews) }\end{array}$ & $\begin{array}{l}\text { AI } \\
\text { (strong } \\
\text { recommendation } \\
\text { based on strong } \\
\text { evidence) }\end{array}$ & $\begin{array}{l}\text { BI } \\
\text { (strong evidence but } \\
\text { has impact on quality } \\
\text { of care) }\end{array}$ & $\begin{array}{l}\text { CI } \\
\text { (recommendations in } \\
\text { this category are } \\
\text { unlikely) }\end{array}$ \\
\hline $\begin{array}{l}\text { II } \\
\text { (well designed cohort } \\
\text { or case controlled } \\
\text { studies) }\end{array}$ & $\begin{array}{l}\text { AII } \\
\text { (moderate evidence, } \\
\text { but the group feels the } \\
\text { issue is very } \\
\text { important) }\end{array}$ & $\begin{array}{l}\text { BII } \\
\text { (moderate evidence, } \\
\text { but moderately } \\
\text { important) }\end{array}$ & $\begin{array}{l}\text { CII } \\
\text { (moderate evidence, } \\
\text { but the group feels the } \\
\text { issue is not } \\
\text { particularly } \\
\text { important) }\end{array}$ \\
\hline $\begin{array}{l}\text { III } \\
\text { (uncontrolled studies) }\end{array}$ & $\begin{array}{l}\text { AIII } \\
\text { (a rare grading, with } \\
\text { no good experimental } \\
\text { evidence, but the } \\
\text { group feel it is very } \\
\text { important, for } \\
\text { example, splenectomy } \\
\text { recommended for } \\
\text { ruptured spleen) }\end{array}$ & $\begin{array}{l}\text { BIII } \\
\text { (limited level of } \\
\text { evidence, but the } \\
\text { group feels } \\
\text { moderately strongly) }\end{array}$ & $\begin{array}{l}\text { CIII } \\
\text { (limited level of } \\
\text { evidence, but might } \\
\text { be considered in some } \\
\text { cases) }\end{array}$ \\
\hline
\end{tabular}

2.1 CATEGORIES OF EVIDENCE

These are graded as follows:

Grade Ia: evidence obtained from metaanalysis of randomised trials.

Grade Ib: evidence obtained from at least one randomised trial.

Grade IIa: evidence obtained from at least one well designed controlled study without randomisation.

Grade IIb: evidence obtained from at least one other type of well designed quasi experimental study.

Grade III: evidence obtained from well designed non-experimental descriptive studies such as comparative studies, correlation studies, and case studies.

Grade IV: evidence obtained from expert committee reports, or opinions or clinical experiences of respected authorities.

The evidence category is indicated after the citations in the reference section.

2.2 GRADING OF RECOMMENDATIONS

The strength of each recommendation is dependent upon the category of the evidence supporting it, and is graded according to the system shown in table 1 .

\subsection{Definitions}

It is important to define the terms that should be used in the context of a variceal bleed. These are the consensus definitions. ${ }^{3}$

3.1 VARICEAL HAEMORRHAGE

Variceal haemorrhage is defined as bleeding from an oesophageal or gastric varix at the time of endoscopy or the presence of large oesophageal varices with blood in the stomach and no other recognisable cause of bleeding. An episode of bleeding is clinically significant when there is a transfusion requirement of 2 units of blood or more within 24 hours of the time zero, together with a systolic blood pressure of less than $100 \mathrm{~mm} \mathrm{Hg}$ or a postural change of greater than $20 \mathrm{~mm} \mathrm{Hg}$ and/or pulse rate greater than 100 beat $/ \mathrm{min}$ at time zero (time zero is the time of admission to the first hospital the patient is taken to).

\subsection{TIME FRAME OF ACUTE BLEEDING}

The acute bleeding episode is represented by an interval of 48 hours from time zero with no evidence of clinically significant bleeding

Abbreviations used in this paper: TIPSS, transjugular intrahepatic portosystemic stent shunt; HVPG, hepatic venous pressure gradient; PCS, portacaval shunts; GOV, gastro-oesophageal varices; IGV, isolated gastric varices; B-RTO, balloon occluded retrograde transvenous obliteration. 
between 24 and 48 hours. Evidence of any bleeding after 48 hours is the first rebleeding episode.

3.3 VARICEAL REBLEEDING

Variceal rebleeding is defined as the occurrence of new haematemesis or malena after a period of 24 hours or more from the 24 hour point of stable vital signs and haematocrit/haemoglobin following an episode of acute bleeding. All bleeding episodes regardless of severity should be counted in evaluating rebleeding.

3.4 FAILURE TO CONTROL ACTIVE BLEEDING The definition of failure to control active bleeding is divided into two time frames:

(i) Failure to control bleeding acute bleeding within six hours:

- Transfusion requirement of 4 units or more and inability to achieve an increase in systolic blood pressure by $20 \mathrm{~mm} \mathrm{Hg}$ or to $70 \mathrm{~mm} \mathrm{Hg}$ or more, and/or inability to achieve a pulse rate reduction to less than $100 \mathrm{beat} / \mathrm{min}$ or a reduction of $20 \mathrm{beat} / \mathrm{min}$ from baseline pulse rate.

(ii) Failure to control bleeding after six hours: any of the following factors

- Occurrence of haematemesis from the six hour point.

- Reduction in blood pressure of more than $20 \mathrm{~mm} \mathrm{Hg}$ from the six hour point and/or increase in pulse rate of more than $20 \mathrm{beat} / \mathrm{min}$ from the six hour point on two consecutive readings an hour apart, transfusion of 2 units of blood or more (over and above the previous transfusions) required to increase the haematocrit to above $27 \%$, or haemoglobin to above $9 \mathrm{~g} / 1$.

3.5 EARLY MORTALITY

Death within six weeks of the initial episode of bleeding.

\subsection{Natural history of varices in cirrhosis} 4.1 DEVELOPMENT OF VARICES

The rise in portal pressure is associated with the development of collateral circulation which allows the portal blood to be diverted into the systemic circulation. These spontaneous shunts occur: (a) at the cardia through the intrinsic and extrinsic gastro-oesophageal veins; (b) in the anal canal where the superior haemorrhoidal vein belonging to the portal system anastomoses with the middle and inferior haemorrhoidal veins which belong to the caval system; (c) in the falciform ligament of the liver through the para-umbilical veins which are the remains of the umbilical circulation of the fetus; (d) in the abdominal wall and the retroperitoneal tissues, from the liver to the diaphragm, veins in the lienorenal ligament, in the omentum and lumbar veins; and (e) blood diversion from the diaphragm, gastric, pancreatic, splenic, and adrenal which may drain into the left renal vein.

Numerous lines of evidence suggest that varices develop and enlarge with time. Christensen and colleagues ${ }^{4}$ followed a cohort of 532 patients with cirrhosis and showed that the cumulative incidence of patients with varices increased from $12 \%$ to $90 \%$ over 12 years. In a study involving 80 patients followed for 16 months, Cales and Pascal ${ }^{5}$ showed that $20 \%$ of patients who did not have varices developed new varices and $42 \%$ of patients with small varices showed definite enlargement. Czaja and colleagues ${ }^{6}$ also showed that the prevalence of varices increased from $8 \%$ to $13 \%$ over five years in a cohort of patients with chronic active hepatitis even though they were treated with prednisolone.

The two factors that appear to determine the development of varices are continued hepatic injury and the degree of portosystemic shunting. Evidence for the former is derived from studies in which varices were shown to regress with time. Baker and colleagues ${ }^{7}$ followed a cohort of 112 patients with oesophageal varices and showed that varices had disappeared in nine patients, regressed in seven, and remained unchanged in six. They concluded that the disappearance and regression of varices may be related to abstinence from alcohol. This observation was confirmed in a study by Dagradi and colleagues $^{8}$ who followed a cohort of patients with alcoholic cirrhosis over three years and showed a reduction in variceal size in 12 of the 15 patients with alcoholic cirrhosis who stopped drinking and an enlargement in variceal size in 17 patients who continued to drink. On the other hand, Cales and Pascal ${ }^{5}$ showed that regression of varices occurred in $16 \%$ of patients with alcoholic cirrhosis who continued to imbibe alcohol. This may be related to the development of large portosystemic collaterals which decompress the portal system.

4.2 RISK FACTORS FOR FIRST VARICEAL BLEEDING The factors that predispose to and precipitate variceal haemorrhage are still not clear. The suggestion that oesophagitis may precipitate variceal haemorrhage has been discarded. ${ }^{9}$ Presently, the most important factors that have been held responsible include: (i) pressure within the varix, (ii) variceal size, (iii) tension on the variceal wall, and (iv) severity of the liver disease.

\subsubsection{Portal pressure}

In most cases, portal pressure reflects intravariceal pressure $^{10}$ and a hepatic venous pressure gradient greater than $12 \mathrm{~mm} \mathrm{Hg}$ is necessary for the development of and bleeding from oesophageal varices but there is no linear relationship between the severity of portal hypertension and the risk of variceal haemorrhage. ${ }^{11}{ }^{12}$ However, the hepatic venous pressure gradient (HVPG) tends to be higher in bleeders as well as in patients with larger varices. In a prospective study comparing propranolol with placebo for the prevention of first variceal haemorrhage, Groszmann and colleagues ${ }^{13}$ showed that bleeding from varices did not occur if the portal pressure gradient could be reduced to less than $12 \mathrm{~mm} \mathrm{Hg}$. This pressure has since been accepted as the aim of pharmacological therapy of portal hypertension. 


\subsubsection{Variceal size}

This is best assessed endoscopically. Variable results in the literature are because of the lack of a definition regarding the distinction between large and small varices. Numerous studies ${ }^{11}{ }^{14}$ have shown that the risk of variceal haemorrhage increases with the size of varices. ${ }^{15}$

\subsubsection{Variceal wall and tension}

Polio and Groszmann ${ }^{16}$ using an in vitro model showed that rupture of varices was related to the tension on the variceal wall. The tension depends on the radius of the varix. In this model, increasing the size of the varix and decreasing the thickness of the variceal wall caused variceal rupture.

Endoscopic features such as "red spots" and "wale" markings were first described by Dagradi. ${ }^{8}$ They have been described as being important in the prediction of variceal haemorrhage. These features represent changes in variceal wall structure and tension associated with the development of microtelangiectasias. In a retrospective study by the Japanese Research Society for Portal Hypertension, Beppu and colleagues ${ }^{17}$ showed that $80 \%$ of patients who had blue varices or cherry red spots bled from varices, suggesting that this was an important predictor of variceal haemorrhage in cirrhosis.

4.2.4 Severity of liver disease and bleeding indices Two independent groups prospectively assessed factors predicting first variceal haemorrhage in cirrhosis prospectively. The North Italian Endoscopic Club (NIEC) ${ }^{18}$ reported their findings in 1988, followed in 1990 by data from the Japanese. ${ }^{19}$ Both of these studies showed that the risk of bleeding was based on three factors: severity of liver disease as measured by Child class, variceal size, and red wale markings. The NIEC study showed a wide range for the risk of bleeding of $6-76 \%$ depending on the presence or absence of the different factors. This index was prospectively validated in a study by Prada and colleagues. ${ }^{20}$ Using the same variables the NIEC index was simplified by De Franchis and colleagues ${ }^{21}$ and shown to correlate with the original index. Further studies showed that the HVPG and intravariceal pressure were also independent predictors of first variceal haemorrhage when analysed in conjunction with the NIEC index. $^{22} 23$

In summary, the two most important factors that determine the risk of variceal haemorrhage are the severity of liver disease and the size of varices. Measurement of HVPG is a useful guide for selection of patients for treatment and their response to therapy.

4.3 RISK OF FIRST VARICEAL BLEED

Data describing the overall risk of bleeding from varices must be viewed with caution and have some pitfalls in interpretation. The natural history of patients who have varices that are diagnosed as part of their work up is different from patients who have complications of liver disease. Patients in trials may represent a different population to patients who have had documented varices and not bled during follow up. Most studies do not comment on either the severity of liver disease or whether patients with alcoholic cirrhosis are continuing to drink. Both these factors have a significant effect on the risk of variceal haemorrhage.

Most studies report bleeding from varices in about $20-50 \%$ of patients with cirrhosis during the period of follow up. Baker and colleagues ${ }^{7}$ reported variceal bleeding in 33 of 115 patients that they followed for a mean of 3.3 years, with a mortality of $48 \%$ from first variceal haemorrhage. These data were confirmed by Christensen and colleagues. ${ }^{4}$ About $70 \%$ of episodes of bleeding occur within two years of diagnosis.

Analysis of the non-active treatment arms in the primary prophylaxis trials comparing propranolol with placebo show results similar to those of the primary prophylaxis shunt trials, with most of the episodes of bleeding occurring within the first two years of follow up. In these studies the rate of first variceal haemorrhage ranged from $22 \%$ to $61 \% .^{24-28}$ This large difference in the rate of first bleed relates almost certainly to the number of patients with severe liver disease included in the study (Pascal, Child C-46\%, bleeding-61\%; IMPP, Child C- $6 \%$, bleeding - 32\%; Conn, Child C-6\%, bleeding-22\%). Mortality varied from $24 \%$ to $49 \%$ over two years (Pascal, mortality-49\%; IMPP, mortality-24\%; Conn, mortality$24 \%)$.

4.4 PROGNOSIS OF ACUTE VARICEAL

HAEMORRHAGE

The average mortality of the first episode of variceal bleeding in most studies is $50 \%$. As discussed, this mortality from variceal haemorrhage is related closely to the severity of liver disease. ${ }^{29-33}$ Over a mean follow up of one year, the average mortality from subsequent variceal haemorrhage is $5 \%$ in Child class A patients, $25 \%$ in Child class B patients, and $50 \%$ in Child class $\mathrm{C}$ patients. Although serum creatinine has been shown in some studies to predict overall survival, ${ }^{34}{ }^{35}$ Child class is superior to any other predictive factor in determining mortality within six weeks or 30 days of the initial haemorrhage (see box 1).

Vinel and colleagues ${ }^{14}$ showed that HVPG was predictive of survival when this was measured at two weeks after the acute bleed. However, it is unclear if this was independent of the severity of liver disease. Whether active bleeding at the time of endoscopy predicts mortality is not clear. Although Cardin and colleagues $^{36}$ found that this was an important factor, Balanzo and colleagues ${ }^{37}$ could not confirm this finding. Active bleeding at the time of endoscopy does however predict early rebleeding. ${ }^{38}$ Risk of death decreases quickly after admission such that the risk of death becomes virtually constant about six weeks after bleeding. ${ }^{39} 40$

\subsection{PRIMARY PROPHYLAXIS}

Since $30-50 \%$ of patients with portal hypertension will bleed from varices and about $50 \%$ will die from the effects of the first bleed, it 


\section{Box 1-Recommendations}

SEVERITY OF CIRRHOSIS

Severity of cirrhosis is best described using the Child-Pugh score. ${ }^{41}$

This form of scoring is the sum of severity scores for the variables shown in table 2 .

Table 2 Severity scores used for calculating the Child-Pugh score

\begin{tabular}{llll}
\hline Category & 1 & 2 & 3 \\
\hline Encephalopathy & 0 & I/II & III/IV \\
Ascites & Absent & Mild-moderate & Severe \\
Bilirubin $(\mu \mathrm{mol} / \mathrm{l})$ & $<34$ & $34-51$ & $>51$ \\
Albumin $(\mathrm{g} / \mathrm{l})$ & $>35$ & $28-35$ & $<28$ \\
INR & $<1.3$ & $1.3-1.5$ & $>1.5$ \\
\hline
\end{tabular}

Child-Pugh class A represents a score of 6 or less, class B a score of 7-9, and class C, 10 or greater.

Patients in class A are least likely to die from the effects of a variceal bleed whereas patients with Child class C disease are most likely to die. (Strength of recommendation grade AI.)

GRADING OF VARICES

Although numerous methods have been described for grading varices, the simplest method is to divide them into three grades:

Grade 1: varices that collapse to inflation of the oesophagus with air.

Grade 2: varices between grades 1 and 3 .

Grade 3: varices which are large enough to occlude the lumen. (Strength of recommendation grade CII.)

seems rational to develop prophylactic regimens to prevent the development of, and bleeding from, these varices. However, most of the published trials do not have sufficient power to identify favourable treatment effects. Based on the expected bleeding and death rates in the control group, the minimum number of patients needed to detect a $50 \%$ reduction in bleeding would be 270 patients, and 850 patients in each arm to detect the same reduction in mortality. A proposed algorithm for surveillance and prophylaxis of varices is shown in fig 1.

\subsubsection{Surgery}

Portacaval shunts. There are four trials in the literature which have randomised a total of 302 patients $^{42-44}$ either to prophylactic shunt surgery or to non-active treatment. A metaanalysis of these studies showed a significant

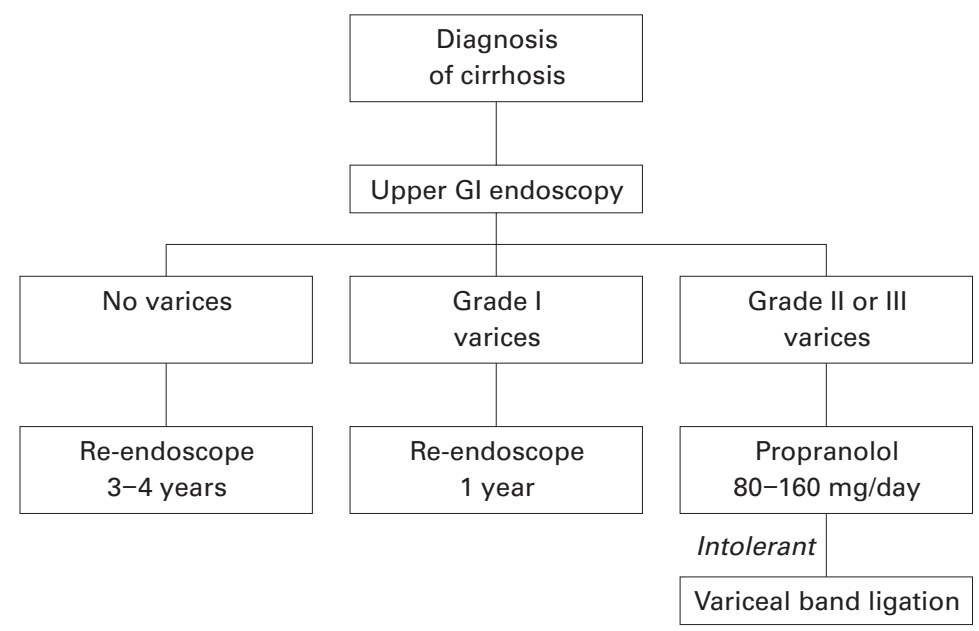

Figure 1 Proposed algorithm for surveillance for varices and primary prophylaxis. benefit in the reduction of variceal bleeding (odds ratio (OR) $0.31,95 \%$ confidence interval (CI) $0.17-0.56)$ but also a significantly greater risk of hepatic encephalopathy (OR 2, 95\% CI $1.2-3.1$ ) and of mortality (OR $1.6,95 \%$ CI 1.02-2.57) in patients treated with shunt surgery.

Devascularisation procedures. Inokuchi and colleagues ${ }^{19}$ showed that there was a significant reduction in variceal bleeding and in mortality in patients treated with a variety of devascularisation procedures. There are, however, numerous problems with the interpretation of this study because of the use of different procedures in each of the 22 centres. These results require confirmation.

\subsubsection{Pharmacological therapy}

Propranolol. The mainstay of the pharmacological approach to the primary prophylaxis of variceal haemorrhage has been propranolol, which has been shown to reduce the portal pressure gradient, reduce azygos blood flow, and also variceal pressure. It achieves this by causing splanchnic vasoconstriction and reducing cardiac output.

There are nine randomised trials assessing its effectiveness: seven are published papers and two are in abstract form. ${ }^{24-28}{ }^{46-49}$ The risk of variceal bleeding was lower in seven studies, ${ }^{24-28} 4648$ significantly lower in four studies, ${ }^{25272846}$ and unchanged in one study. ${ }^{47}$ There was a higher incidence of bleeding in the propranolol group in one study. This was a small study and unbalanced randomisation is likely because of a very low bleeding rate in the control group. ${ }^{49}$ Mortality was reduced in seven trials, ${ }^{24} 22^{28} 286_{46}^{48}$ significantly in one, ${ }^{24}$ and unchanged in two. ${ }^{26}{ }^{27} \mathrm{~A}$ meta-analysis showed that the risk of rebleeding was significantly lower (OR 0.54, 95\% CI 0.39-0.74) but only borderline significance was detected for differences in mortality (OR 0.75, 95\% CI $0.57-1.06) .{ }^{50}$

Isosorbide mononitrate. Interest in the use of vasodilators such as isosorbide mononitrate has grown since the demonstration that it reduces portal pressure as effectively ${ }^{51}$ as propranolol. A trial comparing isosorbide mononitrate with propranolol showed no significant difference between these agents. ${ }^{52}$ $\beta$ Blocker and isosorbide mononitrate. The combination of nadolol and isosorbide mononitrate has been compared with nadolol in a randomised controlled trial. The combination therapy reduced the frequency of bleeding significantly but no significant differences were detected in mortality. ${ }^{53}$

\subsubsection{Endoscopic therapy}

Sclerotherapy. There are 19 trials comparing endoscopic variceal sclerotherapy with no treatment, of which four are in abstract form..$^{214-48}{ }^{54-68}$ These trials include 1630 patients and the studies are significantly heterogeneous. Ten of the trials included only patients with large varices; the other nine include patients with varices of any size. Various sclerosants were used at different doses and injected intra or paravariceally. The results 
Box 2-Recommendations: primary prophylaxis of variceal bleeding in cirrhosis

WHAT IS THE BEST METHOD FOR PRIMARY PROPHYLAXIS?

- Pharmacological therapy with propranolol is the best available modality at present. (Recommendation grade AI.)

- Aim of therapy with propranolol: Reduction in hepatic venous pressure gradient to less than $12 \mathrm{~mm} \mathrm{Hg}$. (Recommendation grade AI).

- Dose: Starting dose $40 \mathrm{mg}$ twice daily, increasing to $80 \mathrm{mg}$ twice daily if necessary. Long acting propranolol at either 80 or $160 \mathrm{mg}$ can be used to improve compliance. (Recommendation grade AI.)

- In case of contraindications or intolerance to propranolol, variceal band ligation is the treatment of choice. (Recommendation grade AI.)

- In difficult situations where neither propranolol nor variceal band ligation can be used, isosorbide mononitrate is the treatment of first choice (20 mg twice daily). (Recommendation grade BI.)

WHO SHOULD HAVE SURVEILLANCE FOR VARICEAL BLEEDING

- All patients with cirrhosis should be endoscoped at the time of diagnosis. (Recommendation grade CI.)

HOW OFTEN SHOULD CIRRHOTIC PATIENTS BE ENDOSCOPED?

- If at the time of first endoscopy no varices are observed, patients with cirrhosis should be endoscoped at three year intervals. (Recommendation grade AII.)

- If small varices are diagnosed, patients should be endoscoped at yearly intervals. (Recommendation grade AII.)

WHICH PATIENTS WITH CIRRHOSIS SHOULD HAVE PRIMARY PROPHYLAXIS

- If grade 3 varices are diagnosed, patients should have primary prophylaxis irrespective of the severity of the liver disease. (Recommendation grade AI.)

- If patients have grade 2 varices and Child class B or C disease, they should have primary prophylaxis. (Recommendation grade BI.)

of these trials are variable with two studies showing a significant reduction in both bleeding and mortality, ${ }^{54} 55$ one study showing a reduction in mortality but no difference in rebleeding, ${ }^{62}$ one study showing a significant increase in the risk of bleeding, ${ }^{59}$ and another significantly greater mortality. ${ }^{65}$ Due to the marked heterogeneity between these studies a meta-analysis is clinically inappropriate. At the present time sclerotherapy cannot be recommended for prophylaxis of variceal haemorrhage in patients with cirrhosis.

Variceal band ligation. Sarin and colleagues ${ }^{69}$ compared variceal band ligation with no active treatment in a randomised study and showed that there was a significant reduction in variceal bleeding in patients treated with band ligation. No significant effect on mortality was found. This observation has been confirmed in a recent study involving about 120 patients. ${ }^{70}$ Variceal band ligation has been compared with propranolol in a randomised controlled trial and shown to reduce the frequency of first bleed significantly without affecting mortality. ${ }^{71}$

Recommendations for the primary prophylaxis of variceal bleeding in cirrhosis are given in box 2 .

\subsection{Management of active variceal haemorrhage}

The most important step in the management of acute variceal haemorrhage is the initial resuscitation and protection of the airway to prevent aspiration. Early endoscopy allows examination of the upper gastrointestinal tract enabling accurate diagnosis of the bleeding site and decision regarding management (fig 2). The following measures of controlling the bleeding are presently available.

5.1 PHARMACOLOGICAL THERAPY

The two major classes of drugs that have been used in the control of acute variceal bleeding are vasopressin or its analogues (either alone or in combination with nitroglycerine) and somatostatin or its analogues.

\subsubsection{Vasopressin}

Vasopressin reduces portal blood flow, portal systemic collateral blood flow, and variceal pressure. It does however have significant systemic side effects such as an increase in peripheral resistance, and reduction in cardiac output, heart rate, and coronary blood flow. In comparison with no active treatment, the pooled results of four randomised trials ${ }^{72-75}$ showed that it reduced failure to control variceal bleeding although mortality was unaffected. Trials comparing sclerotherapy with vasopressin ${ }^{76-79}$ have shown no significant effect on reduction in the failure to control the variceal bleed, except in one study ${ }^{78}$ where rebleeding was significantly lower in patients treated with sclerotherapy.

\subsubsection{Vasopressin with nitroglycerine}

The addition of nitroglycerine enhances its effects on portal pressure and reduces cardiovascular side effects. ${ }^{80}$ Three randomised trials compared vasopressin alone with vasopressin and nitroglycerine $\mathrm{e}^{81-83}$ and the pooled data from these showed that the combination was associated with a significant reduction in failure to control bleeding although no survival benefit was demonstrated.

\subsubsection{Glypressin with or without nitroglycerine}

Glypressin is a synthetic analogue of vasopressin which has an immediate systemic vasoconstrictor action followed by portal haemodynamic effects due to slow conversion to vasopressin. Its efficacy has been assessed in three placebo controlled trials and shown to significantly reduce failure to control bleeding and also to improve survival. ${ }^{84-86}$ Five randomised trials compared its efficacy against vasopressin alone in three ${ }^{848788}$ and two in combination with nitroglycerine. ${ }^{89} 90$ Glypressin significantly reduced failure to control bleeding compared with vasopressin alone and was as good as the combination of vasopressin and nitroglycerine. Three trials compared it with somatostatin and found it to be equally effective. ${ }^{91-93}$ Two trials compared its efficacy against balloon tamponade and found it to be equally effective. ${ }^{9495}$

\subsubsection{Somatostatin and octreotide}

Somatostatin causes selective splanchnic vasoconstriction and reduces portal pressure and portal blood flow. ${ }^{96}$ It was shown to significantly reduce the failure to control bleeding in one trial ${ }^{97}$ and did not show any significant differences against placebo in another. ${ }^{98}$ Seven trials $^{99-105}$ compared its efficacy with 


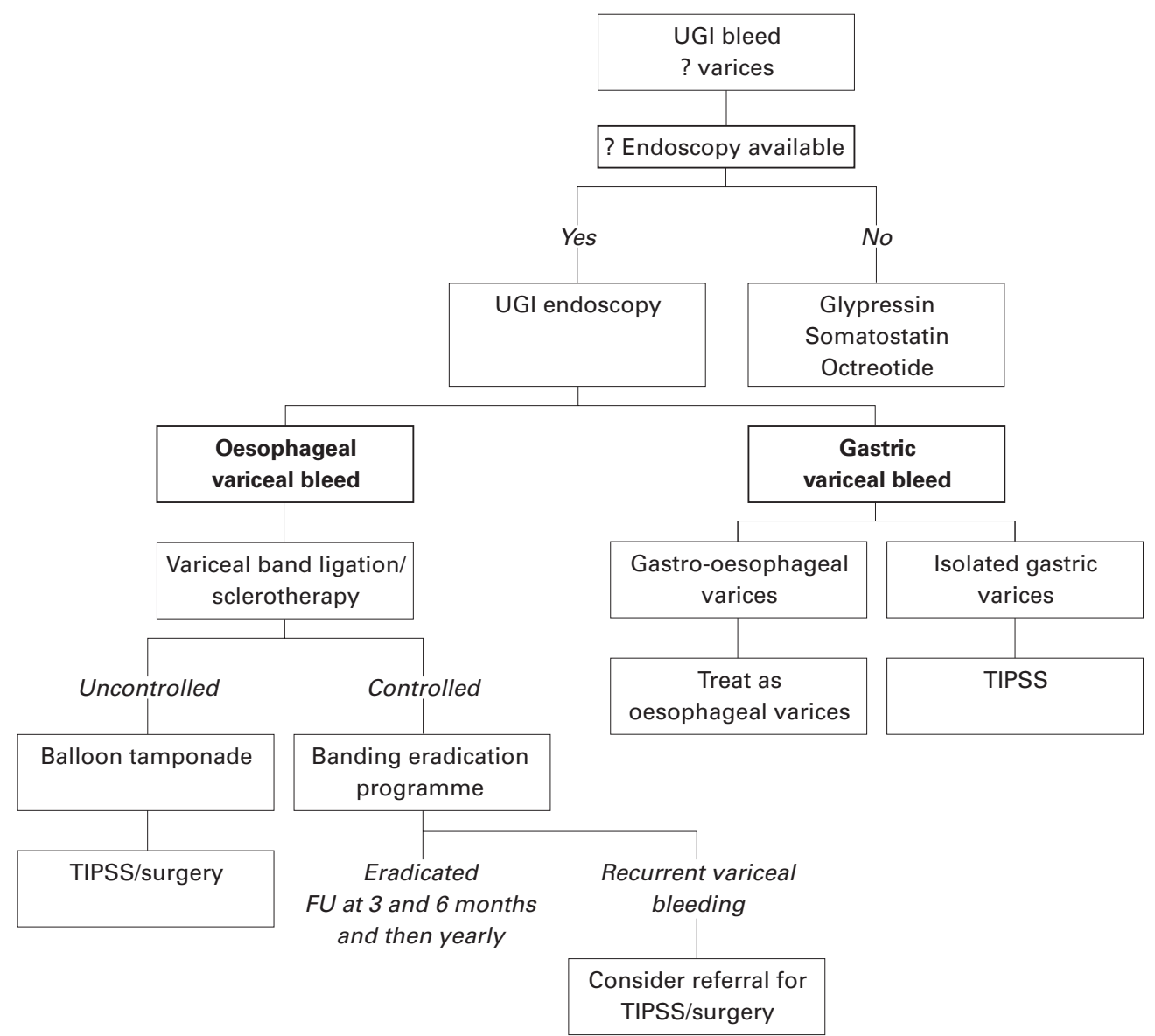

Figure 2 Algorithm for the management of variceal haemorrhage. UGI, upper gastrointestinal; FU, follow up; TIPSS, transjugular intrahepatic portosystemic stent shunt.

vasopressin and showed that somatostatin reduced the failure to control bleeding and was associated with significantly less side effects.

Three trials compared somatostatin with balloon tamponade and showed that these were equally effective in reducing the failure to control variceal bleeding. ${ }^{106-108}$ Five trials have compared somatostatin or its analogue with sclerotherapy ${ }^{109-113}$ and have shown no significant differences in failure to control bleeding, rebleeding, or mortality.

Data from a large randomised trial comparing octreotide with placebo was presented and showed conclusively that there was no significant difference between the two groups in terms of reduction in the failure to control bleeding, amount of blood transfused, or mortality at 42 or 90 days. ${ }^{114}$

\subsection{ENDOSCOPIC THERAPY}

5.2.1 Sclerotherapy

Endoscopic variceal sclerotherapy is based on the concept that bleeding from varices is stopped by thrombosis of the bleeding varix secondary to either intravariceal or paravariceal injection of a sclerosant. In trials of sclerotherapy in acute bleeding there is enormous variation in the type of sclerosant used, the experience of the operator, whether intravariceal or paravariceal injections are used, and the schedule of follow up. Furthermore, interpretation of the results of trials comparing injection sclerotherapy with non-invasive therapy is complicated by inclusion of patients who were not actively bleeding at the time of randomisation. ${ }^{7677}$

Four trials have compared sclerotherapy with balloon tamponade ${ }^{115-118}$ and two of these showed significantly higher control of bleeding in patients treated with sclerotherapy. ${ }^{117}{ }^{118}$ The results of control of bleeding in the sclerotherapy patients are exceptional, at $95 \%$ and $100 \%$, respectively.

Sclerotherapy has been compared with oesophageal transection in four randomised trials ${ }^{119-122}$ and with portacaval shunt in one $\mathrm{e}^{123}$ in patients who had variceal haemorrhage that was uncontrolled. Although all studies showed a reduction in failure to control bleeding in patients treated with surgical therapy, this reached statistical significance in only one. ${ }^{122}$ Rebleeding was also significantly higher in the sclerotherapy group. There were no differences in mortality but the rate of development of encephalopathy was significantly higher in patients treated with the surgical shunt.

\subsubsection{Variceal band ligation}

This technique is a modification of that used for the elastic band ligation of internal haemorrhoids. Its use in humans was first described in $1988^{124}$ and a subsequent randomised clinical trial comparing banding with sclerotherapy showed a significant reduction in the rate of 
Box 3-Recommendations: control of active variceal bleeding in cirrhosis

Ideally patients with variceal bleeding should be treated in a unit where the personnel are familiar with the management of such patients and where routine therapeutic interventions can be undertaken. (Recommendation grade CII.)

(1) RESUSCITATION

- Site: Where haemodynamic monitoring is possible. (Recommendation grade BIII.)

- Methods:

- 16 gauge peripheral cannulae, at least 2 .

- Cross match 6 units of blood.

- Correct prothrombin time, platelet count.

- Central venous access.

- Protection of the airway by elective intubation:

(i) severe uncontrolled variceal bleeding;

(ii) severe encephalopathy;

(iii) inability to maintain oxygen saturation above $90 \%$;

(iv) aspiration pneumonia. (Recommendation grade BIII.)

(2) TIMING OF UPPER GASTROINTESTINAL ENDOSCOPY

- As soon as the patient is haemodynamically stable. (Recommendation grade BIII.)

(3) CONTROL OF BLEEDING

- Variceal band ligation is the method of first choice. (Recommendation grade AI.)

- If banding is difficult because of continued bleeding or this technique is not available, endoscopic variceal sclerotherapy should be performed. (Recommendation grade AI.)

- If endoscopy is unavailable, vasoconstrictors such as octreotide (unlicensed) or glypressin, or a Sengstaken tube inserted (with adequate provision for airways protection) may be used while more definitive therapy is arranged. (Recommendation grade AI.)

(4) FAILURE TO CONTROL ACTIVE BLEEDING

- In case of bleeding that is difficult to control, a Sengstaken tube should be inserted until further endoscopic treatment, TIPSS, or surgical treatment. (Recommendation grade BI.)

- Specialist help should be sought at this time and transfer to a specialist centre should be considered. (Recommendation grade BII.)

- The mode of treatment - that is, surgical intervention such as oesophageal transection or TIPSS - is decided by which of these techniques is routinely used by the centre in which this patient is being managed. (Recommendation grade BII.)

complications and improvement in survival. ${ }^{125}$ Another trial confirmed that banding controls active variceal haemorrhage and no significant differences were found between control of active bleeding between banding and sclerotherapy. Lo and colleagues ${ }^{126}$ showed that active bleeding was controlled more readily with ligation $(94 \%)$ compared with sclerotherapy $(80 \%)$.

\subsubsection{Other endoscopic measures}

Control of bleeding using tissue adhesives such as cyanoacrylate or bucrylate has been reported in about $90 \%$ of cases. ${ }^{127} 128$ There were however similar rates of rebleeding as with sclerotherapy, and there were significant complications in the form of cerebrovascular accidents related to injection of the tissue adhesives and to the risk of damage to the instrument.

5.3 BALLOON TAMPONADE

This form of treatment is highly effective and controls acute bleeding in up to $90 \%$ of patients although about $50 \%$ rebleed when the balloon is deflated. ${ }^{129}$ It is, however, associated with serious complications such as oesophageal ulceration and aspiration pneumonia in up to $15-20 \%$ of patients. Despite this, it may be a life saving treatment in cases of massive uncontrolled variceal haemorrhage pending other forms of treatment.

5.4 TIPSS

Three studies have specifically addressed the role of TIPSS in the management of uncontrolled variceal haemorrhage. ${ }^{130-132}$ They show that TIPSS can be performed successfully in this situation and is associated with rapid control of bleeding. None of these studies was randomised but one study suggested that patients were likely to have a survival benefit if TIPSS was used in the situation of uncontrolled variceal haemorrhage in patients with cirrhosis compared with a historical control group treated with oesophageal transection. A recent study has compared TIPSS with $\mathrm{H}$-graft portacaval shunts in patients who failed non-operative management and suggested that H-grafts were a useful method of reducing portal pressure and had a significantly lower failure rate $(\mathrm{p}<0.02)$. Before wider application, more data are needed. ${ }^{133}$

\subsection{LIVER TRANSPLANTATION}

This is probably only appropriate for patients who bleed while awaiting liver transplantation although studies using variceal band ligation or comparison with the transjugular intrahepatic portal-systemic shunt in this situation need to be done. Liver transplantation is however an exceedingly rare option for the vast majority of patients, both because it is not commonly available and because of shortages and delays in organ procurement. No controlled trials of liver transplantation in uncontrolled/active bleeding are available.

Recommendations for the control of variceal bleeding in cirrhosis are given in box 3 .

\subsection{Secondary prophylaxis of variceal haemorrhage}

This form of treatment is aimed at preventing recurrence of variceal bleeding.

\section{$6.1 \beta$ BLOCKERS}

A total of 755 patients were randomised in 11 trials comparing propranolol or nadolol ${ }^{134}$ with no active treatment. ${ }^{29}$ 30-33 49 134-138 Significant reduction in rebleeding was seen in four trials and a meta-analysis showed significant overall reduction (OR 0.4, 95\% CI 0.3-0.54). Eight trials showed significant reduction in mortality, as did the overall analysis.

\subsection{ENDOSCOPIC THERAPY}

A total of 1111 patients have been randomised to either sclerotherapy or no active treatment in eight trials. ${ }^{76} 1161377^{139-143}$ Rebleeding was significantly reduced in two studies. ${ }^{140} 141$ Overall there was also a significant reduction in rebleeding (OR 0.63 , 95\% CI 0.49-0.79). Mortality was significantly reduced in one study. ${ }^{140}$ Overall there was a significant reduction in mortality (OR $0.77,95 \%$ CI $0.61-$ 0.98). 
Sclerotherapy has been compared with $\beta$ blockers in nine trials which have randomised a total of 787 patients. ${ }^{67137144-150}$ Significant reduction in rebleeding was found in the sclerotherapy group in two studies ${ }^{148} 149$ and an increase was noted in three studies ${ }^{137145147}$ which was not statistically significant. The remainder of the studies showed a reduction in rebleeding which was not statistically significant.

No significant differences were detected in a meta-analysis of 10 trials comparing sclerotherapy with sclerotherapy and $\beta$ blockers. ${ }^{45}$ Two trials comparing sclerotherapy and $\beta$ blockers with $\beta$ blockers alone showed that the combined therapy significantly reduced rebleeding and mortality.

There are now at least seven published randomised trials in the literature comparing sclerotherapy with variceal band ligation which have been combined in a meta-analysis. ${ }^{125} 126$ 151-155 This included 547 patients and concluded that variceal band ligation carried a significantly lower rate of rebleeding (OR 0.52, 95\% CI 0.37-0.74), mortality (OR $0.67,95 \%$ CI $0.46-0.98$ ) and complications such as oesophageal stricture (OR 0.10, 95\% CI 0.03-0.29). These studies comparing the two best available modalities of treatment have shown that variceal band ligation reduces rebleeding, mortality, and local complications.

6.3 TIPSS

Transjugular intrahepatic portosystemic stent shunt (TIPSS) has been compared with sclerotherapy in eight randomised trials ${ }^{156-162}$ and with band ligation in one. ${ }^{163}$ All except one study ${ }^{157}$ comparing TIPSS with sclerotherapy showed a significant reduction in rebleeding in patients treated with TIPSS. One study showed decreased survival ${ }^{157}$ and one study showed improved survival in patients treated with TIPSS. ${ }^{164}$ The other studies showed no significant differences in mortality. The study comparing TIPSS with variceal band ligation plus "TIPSS rescue" showed that patients treated with variceal band ligation had significantly more rebleeding although there was no significant difference in mortality between the groups. A recent meta-analysis comparing TIPSS with endoscopic treatment confirmed that TIPSS reduces rebleeding and is associated with an increased risk of encephalopathy. No differences in survival were observed between patients treated with TIPSS or endoscopic therapy. ${ }^{164 a}$ Despite the problem of shunt insufficiency and the cost of shunt surveillance, TIPSS has been shown to be more cost effective than endoscopic therapy. ${ }^{164 b}$

6.4 SURGERY

6.4.1 Portacaval shunts

Portacaval shunts (PCS) may be either nonselective or selective. Non-selective PCS refer to diversion of portal blood flow into the systemic circulation thereby reducing liver blood flow. Selective shunts (distal splenorenal shunts) refer to drainage of the varices into the systemic circulation without affecting liver blood flow.

Four trials have compared non-selective shunts with no active treatment ${ }^{165-168}$ and all showed a significant reduction in rebleeding; mortality was reduced in three ${ }^{165166168}$ and increased in one. ${ }^{167}$ This difference was thought to be related to the randomisation procedure.

Six trials compared non-selective shunts with the distal splenorenal shunt ${ }^{169-174}$ and included a total of 336 patients. No difference in rebleeding or encephalopathy was observed in any of the studies. Mortality was not significantly different in five of the trials although it was significantly reduced in one. ${ }^{170}$

Distal splenorenal shunt has been compared with sclerotherapy in four randomised trials $^{175-178}$ and with PCS 123179180 in three trials. Shunt surgery was associated with significantly lower rebleeding in five of the trials ${ }^{175-178}{ }^{180}$ and also in a meta-analysis (OR 0.18, 95\% CI $0.12-0.28)$. The incidence of hepatic encephalopathy after shunt surgery was also significantly greater than sclerotherapy in four ${ }^{175-177} 180$ studies and remained unchanged in two. ${ }^{123} 178$ Mortality was increased significantly in the PCS group in one study but overall there were no significant differences.

Recommendations for the secondary prophylaxis of variceal bleeding in cirrhosis are given in box 4 and fig 2 .

\subsection{Gastric varices}

7.1 NATURAL HISTORY

Gastric varices can be detected at the first endoscopy in $20 \%$ of patients with all types of portal hypertension (primary). Within the first two years of eradication of oesophageal varices a further $10 \%$ of patients develop gastric varices (secondary). Primary gastric varices are more commonly observed in patients with portal hypertension due to extrahepatic portal vein obstruction compared with cirrhosis. ${ }^{181} 182$

Gastric varices can be classified on the basis of their location in the stomach and relationship with oesophageal varices. This classification has implications for management. These varices can be divided into: (a) gastrooesophageal varices (GOV), which are associated with oesophageal varices; and (b) isolated gastric varices (IGV), which occur independent of oesophageal varices. Type 1 GOV are continuous with oesophageal varices and extend for $2-5 \mathrm{~cm}$ below the gastro-oesophageal junction along the lesser curvature of the stomach. Type 2 GOV extend beyond the gastrooesophageal junction into the fundus of the stomach. Type $1 \mathrm{IGV}$ refers to varices that occur in the fundus of the stomach and type 2 describes varices anywhere in the stomach including the body, antrum, pylorus, and duodenum. ${ }^{181}$ The most common type of varices seen in cirrhosis is GOV type 1 . Patients who bleed from IGV are at a significantly higher risk of dying from an episode of variceal bleeding compared with patients bleeding from GOV. ${ }^{183}$ 
Box 4-Recommendations: secondary prophylaxis of variceal bleeding in cirrhosis

(1) VARICEAL BAND LIGATION

- Following control of active variceal bleeding the varices should be eradicated using endoscopic methods. The method of first choice is variceal band ligation. (Recommendation grade AI.)

- It is recommended that each varix is banded with a single band at weekly intervals until variceal eradication. (Recommendation grade BII.)

- The use of the over tube should be avoided because this is associated with increased complications. (Recommendation grade BII.)

- Following successful eradication of the varices, patients should be endoscoped at three months and six monthly thereafter. In case of recurrence of varices they should be treated with variceal eradication. (Recommendation grade AII.)

(2) ENDOSCOPIC VARICEAL SCLEROTHERAPY

- If banding is not available, sclerotherapy should be used. (Recommendation grade BI.)

- The sclerosant used may vary between institutions.

- The interval between treatments should be the same as those outlined above for banding. (Recommendation grade AII.)

(3) NON-SELECTIVE $\beta$ BLOCKER WITH OR WITHOUT ENDOSCOPIC THERAPY

- Either combination treatment of sclerotherapy and non-selective $\beta$ blocker or non-selective $\beta$ blocker alone may be used. If the latter strategy is used then it is recommended that patients should have the hepatic venous pressure gradient measured to confirm that this has been successfully reduced to less than $12 \mathrm{~mm} \mathrm{Hg}$. (Recommendation grade AII.)

(4) TIPSS

- TIPSS is more effective than endoscopic treatment in reducing variceal rebleeding but does not improve survival and is associated with more encephalopathy. It is a treatment option that may be used in certain centres with particular expertise. (Recommendation grade AI.) initial control of bleeding was significantly higher in patients treated with cyanoacrylate. Survival was significantly greater in patients treated with cyanoacrylate compared with sclerotherapy. Complications were not significantly different between groups.

Endoscopic injection of thrombin. Injection of bovine thrombin $(1000 \mathrm{U} / \mathrm{ml})$ for bleeding from gastric varices has been used in 11 patients with cirrhosis, bleeding from IGV1 in nine and from GOV1 in two patients. Control of bleeding was observed in all and varices were eradicated in all patients after a mean of two injections. Rebleeding, over a follow up of nine months, occurred in one patient. ${ }^{187}$

Use of Sengstaken tube. Several investigators have shown that immediate control of bleeding can be observed from all types of gastric varices except IGV2, using the Sengstaken-Blakemore tube with the gastric balloon, held under moderate traction. However, rebleeding is almost universal if another modality of treatment is not instituted. ${ }^{129} 181183184188$

Endoscopic band ligation. Gastric variceal band ligation using "O" rings and detachable snares have been shown to control active bleeding from gastric varices but is followed almost invariably by recurrence of bleeding. ${ }^{189190}$ No controlled data are available on the use of this treatment approach. However, given the anatomy of gastric varices it may be dangerous to band them.

\subsubsection{Surgery}

Under running of gastric varices ${ }^{191}$ has been shown to control active bleeding but is followed by recurrence of bleeding in $50 \%$ of patients and is associated with a perioperative mortality of greater than $40 \%$. Complete devascularisation of the cardia, stomach, and distal oesophagus for bleeding from gastric varices is associated with good control of bleeding but is followed by rebleeding in over $40 \%$ of patients and early mortality in about $50 \% .{ }^{192}$ The use of distal splenorenal shunting for bleeding from gastric varices in patients with cirrhosis has been poorly studied and its use has been reported in six patients with Child class A or B cirrhosis. Although good control of bleeding was attained, two patients died in the postoperative period. ${ }^{193}$

bleeding from all types of gastric varices about $70-80 \%$ of patients with gastric variceal bleeding. ${ }^{184} 185$ However, active bleeding was arrested with sclerotherapy in only $26 \%$ of patients with $\mathrm{IGV}^{151}$. In addition, rebleeding after endoscopic sclerotherapy occurred in $60-90 \%$ of patients in the different studies. ${ }^{151} 184185$ Episodes of rebleeding are more common in patients with IGVs. ${ }^{151} 184185$

Endoscopic injection therapy with "super glue". Several studies have used cyanoacrylate for the treatment of oesophagogastric varices. Soehendra and colleagues ${ }^{128}$ used it successfully to eradicate gastric varices. Ramond and colleagues ${ }^{127}$ used cyanoacrylate to treat gastric varices in 27 patients and reported successful control of active bleeding in $90 \%$ of patients who were actively bleeding but $50 \%$ rebled. In a controlled but non-randomised study comparing butyl cyanoacrylate with sclerotherapy, Oho and colleagues ${ }^{186}$ showed that the rate of

\subsubsection{Radiology}

The use of "balloon occluded retrograde transvenous obliteration" (B-RTO) for the treatment of bleeding gastric varices has been pioneered by the Japanese. ${ }^{194} 195$ This procedure involves insertion of a balloon catheter into an outflow shunt (gastric-renal or gastric-inferior vena caval) via the femoral or internal jugular vein. Blood flow is blocked by inflation of the balloon and then $5 \%$ ethanolamine oleate iopamidol is injected in a retrograde manner. The use of this technique has been described in about 60 patients. Good control of bleeding was observed in all patients and recurrence of varices occurred in about $10 \%$. However, no controlled data for the use of this technique are available. 
Box 5-Recommendations

CLASSIFICATION OF GASTRIC VARICES

Primary

- Gastric varices that can be detected at the first endoscopy.

Secondary

- Those gastric varices that occur within two years of eradication of oesophageal varices.

Types of gastric varices

- Gastro-oesophageal varices types 1 and 2 (GOV): those gastric varices that are continuous with oesophageal varices and occur along the lesser curvature or the fundus, respectively.

- Isolated gastric varices types 1 and 2 (IGV): those gastric varices that are discontinuous from the oesophageal varices and occur either in the fundus of the stomach or anywhere else in the stomach, including the body, antrum, pylorus, and duodenum, respectively. (Recommendation grade BII.)

MANAGEMENT OF ACTIVE BLEEDING FROM GASTRIC VARICES

Gastro-oesophageal varices

- Treat as for oesophageal varices. (Recommendation grade BII.)

Isolated gastric varices

- Initial therapy: injection sclerotherapy with either sclerosants, butyl-cyanoacrylate, or thrombin. (Recommendation grade BII.)

- In case of failure to control bleeding: balloon tamponade with Sengstaken-Blakemore tube. (Recommendation grade BII.)

- For long term control of variceal bleeding: TIPSS or shunt surgery. (Recommendation grade BII.)

\subsubsection{TIPSS}

TIPSS has been shown to control active bleeding from gastric varices in almost all patients in whom the shunt can be performed successfully. ${ }^{132} 196197$ Procedure related mortality is about $1 \%$ and rebleeding occurs with shunt insufficiency in about $15 \%$ of patients. ${ }^{197}$ In a comparative study, evaluating the clinical outcome of patients treated with TIPSS for variceal bleeding from oesophageal and gastric varices, no significant differences were detected in the rate of control of bleeding, rebleeding, or survival. ${ }^{197}$ TIPSS appears to be an effective method of treating gastric variceal bleeding. However, no randomised clinical trials comparing TIPSS with any other form of therapy are available.

Recommendations for the management of gastric varices are given in box 5 .

\subsection{Antibiotics in variceal bleeding}

Bacterial infections occur in about $20 \%$ of patients with cirrhosis with upper gastrointestinal bleeding within 48 hours of admission $^{198}$ and the incidence increases to $35-66 \%$ within two weeks. ${ }^{199-201}$ Prognosis both in terms of rebleeding, failure to control bleeding, and inhospital outcome are closely related to bacterial infections. ${ }^{199-201}$ Six randomised controlled trials have compared antibiotic prophylaxis with no treatment. ${ }^{202-207}$ Five of the fully published papers were combined in a

\section{Box 6-Recommendations}

- Infection is common after upper gastrointestinal bleeding in cirrhotic patients and a major cause of morbidity and mortality.

- All patients presenting with an episode of variceal bleed should have antibiotic prophylaxis.

- It is suggested that they be treated with ciprofloxacin $1 \mathrm{~g} /$ day for seven days. meta-analysis. ${ }^{202-206,}{ }^{208}$ Fluoroquinolines were used in four of the trials ${ }^{203-206}$ combined with amoxycillin and clavulinic acid in two, ${ }^{204,205}$ and oral non-absorbable antibiotics in one. ${ }^{202}$ The results show that antibiotic prophylaxis was associated with a significantly lower rate of infection, bacteraemia, and spontaneous bacterial peritonitis. Antibiotic prophylaxis was associated with significantly improved short term survival (mean improvement rate 9.1\% (95\% CI 2.9-15.3); p<0.004). The above would suggest that patients with cirrhosis and upper gastrointestinal bleeding should have antibiotic prophylaxis. The choice of the antibiotic and its dose is debatable and should be decided upon by the policy of the unit where the patient is being treated. However, most of the present studies have used fluoroquinolines and therefore the evidence dictates the use of a fluoroquinoline (ciprofloxacin) as the simplest measure at a dose of $1 \mathrm{~g}$ per day orally.

The authors gratefully acknowledge the contribution of the members of the Liver Section, British Society of Gastroenterology.

\subsection{References}

1 Eccles M, Clapp Z, Grimshaw J, et al. North of England evidence based guidelines development project: methods of guideline development. BMF 1996;312:760-2.

Grade: IV Grimshaw J, Eccles M, Russel I, et al. Developing clinically
valid practice guidelines. $\mathcal{F}$ Evaluation Clin Pract 1995;1:3748 .

3 De Franchis R. Developing concensus in portal hypertension. F Hepatol 1996;25:390-4.

Grade: IV

4 Christensen E, Fauerholdt L, Schlichting P, et al. Aspects of the natural history of gastrointestinal bleeding in cirrhosis and the effect of prednisone. Gastroenterology 1981;81:94452.

5 Cales P, Pascal JP. Natural history of ex: III cirrhosis (from origin to rupture). Gastroenterol Clin Biol 1990;12:245-54.

6 Czaja AJ, Wolf AM, Summerskill WH. Development and early prognosis of esophageal varices in severe chronic early prognosis of esophageal varices in severe chronic
active liver disease (CALD) treated with prednisolone. active liver disease (CALD) treat
Gastroenterology 1979;77:629-33.

Grade: III

7 Baker LA, Smith C, Lieberman G. The natural history of esophageal varices. Am f Med 1959;26:228-37.

8 Dagradi A. The natural history of esophageade: III patients with alcoholic liver disease. Am $\mathcal{f}$ Gastroenterol 1972;57:520-40.

9 MacDougall BR, Westaby D, Theodossi A, Dawson JL, Williams $R$. Increased long-term survival in variceal haemorrhage using injection sclerotherapy. Results of a controlled trial. Lancet 1982;1:124-7.

Grade: Ib

10 Dawson J, Gertsch P, Mosimann F, et al. Endoscopic variceal pressure measurements: Response to isosorbide dinitrate. Gut 1985;26:843-7.

11 Lebrec D, De Fleury P, Rueff B, al . Portal hrade: IIb size of esophageal varices, and risk of gastrointestinal bleeding in alcoholic cirrhosis. Gastroenterology 1980;79: 1139-44. GarciaTsao G, Groszmann RJ, Fisher RL, et al. Portal pressure, presence of gastroesophageal varices and variceal bleeding. Hepatology 1985;5:419-24.

Grade: III

13 Groszmann RJ, Bosch J, Grace ND, et al. Hemodynamic events in a prospective randomized trial of propranolol versus placebo in the prevention of a first variceal hemorrhage. Gastroenterology 1990;99:1401-7.

Grade: Ib

14 Vinel JP, Cassingeul J, Levade M, et al. Assessment of short term prognosis after variceal bleeding in patients with alcoholic cirrhosis by early measurement of porto-hepatic gradient. Hepatology 1986;6:116-17.

15 Palmer ED, Brick IB. Correlation between severity of esophageal varices in portal cirrhosis and their propensity toward hemorrhage. Gastroenterology 1956;30:85-90. 
16 Polio J, Groszmann RJ. Hemodynamic factors involved in the development and rupture of esophageal varices: A pathophysiologic approach to treatment. Semin Liver Dis 1986;6:318-31.

Grade: III

17 Beppu K, Inokuchi K, Koyanagi N, et al. Prediction of variceal hemorrhage by esophageal endoscopy. Gastrointest Endosc 1981;27:213-18.

Grade: III

18 North Italian Endoscopic Club (NIEC) for the study and treatment of esophageal varices. Prediction of first variceal
haemorrhage in patients with cirrhosis of the liver and esophageal varices. A prospective multicenter study. $N$ Engl fMed 1988;319:983-9.

Grade: Ib

19 Inokuchi K, Sugimachi K, Sato T, et al. Improved survival after prophylactic portal nondecompression surgery for esophageal varices: A randomized clinical trial. Hepatology 1990;12:1-6.

Grade: Ib

20 Prada A, Bortoli A, Minoli G, Carnovali M, Colombo E, Sangiovanni A. Prediction of oesophageal variceal bleeding: Evaluation of the beppu and North Italian Endo-
scopic Club scores by an independent group. Eur f Gastroenterol Hepatol 1994;6:1009-13.

Grade: III

21 De Franchis R, Primignani M, Arcidiacono PG, et al. Prophylactic sclerotherapy in high-risk cirrhotics selected by endoscopic criteria: A multicenter randomized controlled trial. Gastroenterology 1991;101:1087-93.

2 Feu $F$, Del Arbol $L R$, Banares $R$, Planas $R$, Ar, Bosch J. Double-blind randomized controlled trial comparing terlipressin and somatostatin for acute variceal hemorrhage. Gastroenterology 1996;111:1291-9.

Grade: Ib

23 Merkel C, Bolognesi M, Bellon S, et al. Prognostic usefulness of hepatic vein catheterization in patients with cirrhosis and esophageal varices. Gastroenterology 1992;102: 973-9.

Grade: IIb

24 Pascal JP, Cales P and Multicentre Study Group. Propranolol in the prevention of first upper gastrointestinal
tract hemorrhage in patients with cirrhosis of the liver and tract hemorrhage in patients with cirrhosis of the liver
esophageal varices. $N$ Engl f Med 1987;317:856-61.

Grade: Ib

25 Ideo G, Bellati G, Fesce E, Grimoldi D. Nadolol can preven the first gastrointestinal bleeding in cirrhotics: A prospective, randomized study. Hepatology 1988;8:6-9.

Grade: Ib

26 Lebrec D, Poynard T, Capron JP, et al. Nadolol for prophylaxis of gastrointestinal bleeding in patients with cirrhosis A randomized trial. $\mathcal{F}$ Hepatol 1988;7:118-25.

27 Italian Multicenter Project for Propranolol in Preve Bleeding. Propranolol prevents first gastro Bleeding. Propranolol prevents first gastrointestinal bleeding in non-ascitic cirrhotic patients. Final report
center randomized trial. $\mathcal{F}$ Hepatol 1989;9:75-83.

Grade: Ib

28 Conn HO, Grace ND, Bosch J, et al. Propranolol in the prevention of the first hemorrhage from esophagogastric varices: A multicenter, randomized controlled clinical trial. Hepatology 1991;13:902-12.

Grade: Ib

29 Lebrec D, Poynard T, Bernuau J, et al. A randomized controlled study of propranolol for prevention of recurrent gastrointestinal bleeding in patients with cirrhosis: a final report. Hepatology 1984;4:355-8.

Grade: Ib

30 Burroughs AK, Jenkins WJ, Sherlock S, et al. Controlled trial of propranolol for the prevention of recurrent variceal hemorrhage in patients with cirrhosis. N Engl F Med 1983; 309:1539-42.

Grade: Ib

31 Villeneuve JP, Pomier-Layrargues G, Infante-Rivard C, et al Propranolol for the prevention of recurrent variceal haemorrhage: a controlled trial. Hepatology 1986;6:123943.

Grade: Ib

32 Colombo M, De Franchis R, Tommasini M, Sangiovanni A Dioguardi $\mathrm{N}$. beta-Blockade prevents recurrent gastrointestinal bleeding in well-compensated patients with alcoholic cirrhosis: A multicenter randomized controlled trial. Hepatology 1989;9:433-8.

Grade: Ib

33 Garden OJ, Mills PR, Birnie GG, Murray GD, Carter DC. Propranolol in the prevention of recurrent variceal hemorrhage in cirrhotic patients. A controlled trial. Gastroenterology 1990;98:185-90.

Grade: Ib

34 Garden OJ, Motyl H, Gilmour WH, et al. Prediction of outcome following acute variceal haemorrhage. $\mathrm{Br}$ f Surg 1985;72:91-5.

Grade: III

35 Christensen E, Krintel JJ, Hansen M, Krogh S, et al. Prognosis after the first episode of gastrointestinal bleeding or coma in cirrhosis. Scand $\mathcal{F}$ Gastroenterol 1989;24:999or com

Grade: III

36 Cardin F, Gori G, McCormick PA, Burroughs AK. A predictive model for very early rebleeding from varices. Gut 1990;31:A1204 (abstract)

Grade: III
37 Balanzo J, Villanueva C, Espinos J, et al. Predictive value of the endoscopic signs in variceal bleeding. $f$ Hepatol 991;13:(suppl 2):S93 (abstract).

Grade: III

38 Siringo S, McCormick PA, Mistry P, Kaye G, McIntyre N, Burroughs AK. Prognostic significance of the white nipple sign in variceal bleeding. Gastrointest Endos 1991;37:51-5.

Grade: III

39 Graham DY, Smith JL. The course of patients after variceal haemorrhage. Gastroenterology 1981;80:800-9.

Grade: III

0 Burroughs AK, Mezzanote G, Phillips A, Aiden McCormick P, McIntyre N. Cirrhotics with variceal haemorrhage: The importance of the time interval between admission and the start of analysis for survival and rebleeding rates. Hepatology 1989;9:810-17.

Grade: II

41 Pugh RMN, Murray-Lyon IM, Dawson JL, et al. Transection of the oesophagus for bleeding oesophageal varices. $\mathrm{Br}$ f Surg 1973;60:646-9.

Grade: III

42 Conn HO, Lindenmuth Ww, May CJ, Ramsby GR. Prophylactic portacaval anastomosis in cirrhotic patients
with esophageal varices. N Engl $\mathcal{F}$ Med 1965;272:1255-63.

43 Jackson FC, Perrin EB, Smith AG, Dagradi AE, Nadal HM. A clinical investigation of the portacaval shunt. II. Survival
analysis of the prophylactic operation. Am $\mathcal{F}$ Surg $1968 ; 115$ : $22-42$.

Grade: III

44 Resnick RH, Chalmers TC, Ishihara AM, et al. A controlled trial of the prophylactic portacaval shunt. A final report. Ann Intern Med 1969;70:675-88.

Grade: Ib

45 D'Amico G, Pagliaro L, Bosch J. The treatment of portal hypertension: A meta-analytic review. Hepatology 1995;22: 332-54.

Grade: Ia

46 Andreani T, Poupon RE, Balkau BJ, et al. Preventive therapy of first gastrointestinal bleeding in patients with cirrhosis: Results of a controlled trial comparing propranolol, Results of a controlled trial comparing propranolol,
endoscopic sclerotherapy and placebo. Hepatology 1990;12: endoscopic

Grade: Ib

47 The PROVA Study Group. Prophylaxis of first hemorrhage from oesophageal varices by sclerotherapy, propranolol or both in cirrhotic patients. A randomised multicenter trial. Hepatology 1991;14:1016-24.

Grade: Ib

48 Strauss E, de Sa MFG, Albano A, Lacet CMC, Leite MO, Maffei RA Jr. A randomised controlled trial for the prevention of the first upper gastrointestinal bleeding due to portal hypertension in cirrhosis: sclerotherapy or propranolol versus control groups. Hepatology 1988;8:1395 (abstract).

49 Colman J, Jones P, Finch C, Dundley F. Propranolol in the prevention of variceal hemorrhage in alcoholic cirrhotic patients. Hepatology 1990;12:851 (abstract).

50 Hayes PC, Davis JM, Lewis JA, Bouc analysis of the value of propranolol in the prevention of variceal haemorrhage. Lancet 1990;336:153-6.

Grade: Ia

51 Navasa M, Chesta J, Bosch J, Rodes J. Reduction of portal pressure by iso-sorbide-5-mononitrate in patients with cirrhosis. Effects upon splanchnic and systemic haemodynamics and liver function. Gastroenterology 1989;96:111018.

Grade: IIb

52 Angelico M, Carli L, Piat C, et al. Isosorbide-5-mononitrate versus propranolol in the prevention of first bleeding in cirhosis. Gastroenterology 1993;104:1460-5.

Grade: Ib

53 Merkel C, Marin R, Enzo E, et al. Randomised trial of nadolol alone or with isosorbide mononitrate for primary prophylaxis of variceal bleeding in cirrhosis. GruppoTriveneto per L'ipertensione portale. $N$ Engl $f$ Med 1996;334:1624-9.

Grade: Ib

54 Paquet KJ, Koussouris P. Is there an indication of prophylactic endoscopic paravariceal injection sclerotherapy in patients with liver cirrhosis and portal hypertension? Endoscopy 1986;18:32-5.

Grade: IV

55 Witzel L, Wolbergs E, Merki H. Prophylactic endoscopic sclerotherapy of oesophageal varices. A prospective conrolled study. Lancet 1985;1:773-5.

Grade: Ib

56 Koch H, Henning H, Grimm H, Soehendra N. Prophylactic sclerosing of esophageal varices-Results of a prospective controlled study. Endoscopy 1986;18:40-3.

Grade: Ib

57 Kobe E, Zipprich B, Schentke KU, Nilius R. Prophylactic endoscopic sclerotherapy of esophageal varices-A prospective randomized trial. Endoscopy 1990;22:245-8.

58 Wordehoff D, Spech HJ. Prophylaktische OsophagusVarizensklerosierung: Ergebnisse Einer Prospektiven, Randomisierten Langzeitstudie uber 7 Jahre (Prophylactic sclerotherapy of esophageal varices: Results of a prospecsclerotherapy of esophageal varices: Results of a prospecMedizinische Wochenschrift 1987;112:947-51. 
59 Santangelo WC, Dueno MI, Estes BL, Krejs GJ. Prophylactic sclerotherapy of large esophageal varices. $N$ Engl f Med tic sclerotherapy of

Grade: Ib

60 Sauerbruch T, Wotzka R, Kopcke W, et al. Prophylactic sclerotherapy before the first episode of variceal hemorrhage in patients wih cirrhosis. N Engl f Med 1988;319:8-15.

Grade: Ib

61 Piai G, Cipolletta L, Claar M, et al. Prophylactic sclerotherapy of high-risk esophageal varices: Results of a multicentric prospective controlled trial. Hepatology 1988; 8:1495-500.

Grade: Ib

62 Potzi R, Bauer P, Reichel W, Kerstan E, Renner F, Gangl A. Prophylactic endoscopic sclerotherapy of oesophageal varices in liver cirrhosis. A multicentre prospective controlled randomised trial in Vienna. Gut 1989;30:873 9

Grade: Ib

63 Russo A, Giannone G, Magnano A, Passanisi G, Longo C. Prophylactic sclerotherapy in nonalcoholic liver cirrhosis: trial. World f Surg 1989;13:149-53.

Grade: Ib

64 Triger DR, Smart HL, Hosking SW, Johnson AG. Prophylactic sclerotherapy for esophageal varices: Long-
term results of a single-center trial. Hepatology 1991;13: term result $117-23$.

Grade: Ib

65 VA Cooperative Variceal Sclerotherapy Group. Sclerotherapy for male alcoholic cirrhotic patients who have bled for esophageal varices: results of a randomized multicenter clinical trial. Hepatology 1994;20:618-25.

Grade: Ib

66 Saggioro A, Pallini P, Vitalba A, et al. Complications of the endoscopic sclerotherapy of oesophageal varices: Comparison between different techniques. Policlinico - Sezione Chirurgica 1987;94:461-4.

Grade: IIa

67 Fleig WE, Stance EF, Hunecke R, et al. Prevention of recurrent bleeding in cirrhotics with recent variceal hemorrhage:
Prospective, randomized comparison of propranolol and sclerotherapy. Hepatology 1987;7:355-61.

Grade: Ib

68 Planas R, Boix J, Dominguez M, et al. Prophylactic sclerosis of esophageal varices. Prospective trial. F Hepatol 1989;9 (suppl 1):S73 (abstract)

Grade: Ib

69 Sarin SK, Guptan RKC, Jain AK, Sundaram KR. A randomized controlled trial of endoscopic variceal band ligation for primary prophylaxis of variceal bleeding. Eur $\mathcal{F}$ Gastroenterol Hepatol 1996;8:337-42.

Grade: $\mathbf{I b}$

70 Lay CS, Tsai YT, Teg CY, et al. Endoscopic variceal ligation in prophylaxis of first variceal bleeding in cirrhotic patients
with high-risk esophageal varices. Hepatology 1997;25: with high

Grade: Ib

71 Sarin SK, Lamba GS, Kumar M, Misra A, Murthy NS. Comparison of endoscopic ligation and propranolol for the primary prevention of variceal bleeding. $N \mathrm{Engl} \mathcal{F} \mathrm{Med}$ 1999;340:988-93.

Grade: Ib

72 Merigan TC, Plotkin GR, Davidson CS. Effect of intravenously administered posterior pituitary extract on hemorrhage from bleeding esophageal varices. $N$ Engl $\mathcal{f}$ Med 1962;266:134-5.

Grade: IIb

73 Conn HO, Ramsby GR, Storer EH, et al. Intraarterial vasopressin in the treatment of upper gastrointestinal
hemorrhage: a prospective controlled clinical trial. Gastroenterology 1975;68:211-21.

Grade: IIa

74 Mallory A, Schaefer JW, Cohen JR, Holt AS, Norton LW. Selective intra-arterial vasopressin infusion for upper gastrointestinal tract hemorrhage. A controlled trial. Arch Surg 1980;115:30-2.

Grade: Ib

75 Fogel MR, Knauer CM, Andres LL, et al. Continuous intravenous vasopressin in active upper gastrointestinal bleeding. A placebo-controlled trial. Ann Intern Med 1982;96: 565-9.

Grade: Ib

76 Soderlund C, Ihre T. Endoscopic sclerotherapy v. conservative management of bleeding esophageal varices. Acta Chir tive management of blee
Scand 1986;151:449-56.

Grade: Ib Larson AW, Cohen $\mathrm{H}$, Zwieiban BA, et al. Acute esophageal
variceal sclerotherapy. $\mathscr{f} A M A$ 1986;255:497-500.

Grade: IV

78 Alexandrino P, Alves MM, Fidalgo P, et al. Is sclerotherapy the first choice treatment for active variceal bleeding in cirrhotic patients? Final report of a randomised clinical trial. $\mathcal{F}$ Hepatol 1990;11(suppl):S1.

Grade: Ib

79 Westaby D, Hayes PC, Gimson AES, Polson R, Williams R. Controled clinical trial of injection sclerotherapy for active variceal bleeding. Hepatology 1989;9:274-7.

Grade: Ib

80 Groszmann RJ, Kravetz D, Bosch J, et al. Nitroclycerin improves the hemodynamic response to vasopressin in portal hypertension. Hepatology 1982;2:757-62.
81 Tsai YT, Lay CS, Lai KH, et al. Controlled trial of vasopressin plus nitroglycerin vs vasopressin alone in the treatment of bleeding esophageal varices. Hepatology 1986; 6:406-9.

Grade: Ib

82 Gimson AES, Westaby D, Hegarty J, Alastair W, Williams R. A randomized trial of vasopressin plus nitroglycerin in the control of acute variceal hemorrhage. Hepatology 1986;6: 410-13.

Grade: Ib

83 Bosch J, Groszman RJ, Garcia-Pagan JC, et al. Association of transdermal nitroglycerin to vasopressin infusion in the treatment of variceal hemorrhage: a placebo-controlled clinical trial. Hepatology 1989;10:962-8.

84 Freeman JG, Cobden MD, Record CO. Placebo-controlled trial of terlipressin (glypressin) in the management of acute variceal bleeding. F Clin Gastroenterol 1989;11:58-60.

Grade: Ib

85 Soderlund C, Magnusson I, Torngren S, Lundell L. Terlipressin (triglycyl-lysine vasopressin) controls acute bleeding oesophageal varices. A double-blind, randomized, placebo-controlled trial. Scand f Gastroenterol 1990;25: 622-30.

Grade: Ib

86 Levacher S, Blaise M, Paterson D, Letoumelin PH, Lepandry C, Pourriat JL. Early administration of terlipressin plus transdermal nitroglycerin of active upper gastrointestinal hemorrhage in cirrhotic patients. F Hepatol 1994;21:S46 (abstract).

87 Desaint B, Florent C, Levy VG. A randomised trial of triglycyl-lysine vasopressin versus lysine vasopressin in triglycyl-lysine vasopressin versus lysine vasopressin in eds. Vasopressin analogs and portal hypertension. Paris: John Libbey Eurotext, 1987:155-7.

Grade: Ib

88 Chiu WK, Sheen IS, Liaw YR. A controlled study of glypressin versus vasopressin in the control of bleeding from esophageal varices. $\mathcal{F}$ Gastroenterol Hepatol 1990;5: 549-53.

Grade: Iia

89 Lee YF, Tsay YT, Laid KH, et al. A randomised controlled study of triglycyl-vasopressin and vasopressin plus nitroglycerin in the control of acute esophageal variceal hemorrhage. Chin f Gastroenterol 1988;5:131-8.

Grade: Ib

90 D'Amico G, Traina M, Vizzini G, et al. Terlipressin or vasopressin plus transdermal nitroglycerin in a treatment stratpressin plus transdermal nitroglycerin in a treatment stratcal trial. f Hepatol 1994;20:206-12.

Grade: Ib

91 Silvain C, Carpentier S, Sautereau D, et al. Terlipressin plus transdermal nitroglycerin vs octreotide in the control of acute bleeding from esophageal varices: a multicenter randomized trial. Hepatology 1993;18:61-5.

Grade: Ib

92 Walker S, Kreichgauer HP, Bode JC. Terlipressin vs somatostatin in bleeding esophageal varices: a controlled double blind study. Hepatology 1992;15:1023-30.

Grade: Ib

93 Variceal Bleeding Study Group. Hospitals Cinic (Barcelona), Germans Trias (Badalona), Gregorio Maranon (Madrid), Ramon y Cajal (Madrid). Double blind comparison of somatostatin infusion vs glypressin injection in the treatment of acute variceal hemorrhage in patients with cirrhosis. $\mathcal{F}$ Hepatol 1993;18(suppl 1):S37 (abstract).

Grade: Ib

94 Colin R, Giuli N, Czernichow P, Ducrotte P, Lerebours E. Prospective comparison of glypressin, tamponade and their association in the treatment of bleeding esophageal. In: Lebrec D, Blei AT, eds. Vasopressin analogs and portal hypertension. Paris: John Libbey Eurotext, 1987:149-53.

Grade: IV

95 Fort E, Sautereau D, Silvaine C, Ingrand P, Pillegand B, Beauchant M. A randomised trial of terlipressin plus nitroglycerin vs balloon tamponade in the control of acute vasopressin hemorrhage. Hepatology 1990;11:678-81.

Grade: Ib

96 Bosch J, Kravetz D, Rodes J. Effects of somatostatin on hepatic and systemic hemodynamics in patients with cirrhosis of the liver. Comparison with vasopressin. Gastroenterology 1981;80:518-25.

Grade: IIb

97 Burroughs AK, McCormick PA, Hughes MD, Sprengers D, D'Heygere F, McIntyre N. Randomized, double-blind, placebo-controlled trial of somatostatin for variceal bleeding: Emergency control and prevention of early variceal rebleeding. Gastroenterology 1990;99:1388-95.

Grade: Ib

98 Valenzuela JE, Schubert T, Fogel MR, et al. A multicenter, randomized, double-blind trial of somatostatin in the management of acute hemorrhage from esophageal varices. Hepatology 1989;10:958-61.

Grade: Ib

99 Kravetz D, Bosch J, Teres J, et al. Comparison of intravenous somatostatin and vasopressin infusions in treatment of acute variceal hemorrhage. Hepatology 1984;4:442-6.

00 Jenkins SA, Baxter IN, Corbett W, et al. A prospective: Ib domised controlled clinical trial comparing somatostatin and vasopressin in controlling acute variceal haemorrhage. BMF 1985;290:275-8. 
101 Bagarani M, Albertini V, Anza M, et al. Effect of somatostatin in controlling bleeding from esophageal somatostatin in controlling bleeding
varices. Ital f Surg Sci 1987;17:21-6.

Grade: III

102 Cardona C, Vida F, Balanzo J, Cusso X, Farre A, Guarner C. Eficacia terapéutica de la somatostatina versus vasopressina mas nitroglycerina en la hemorragia activa por varices esofagogastrica. Gastroenterol Hepatol 1989;12:30-4

Grade: Ib

103 Hsia HC, Lee FY, Tsai YT, et al. Comparison of somatostatin and vasopressin in the control of acute trolled study. Chin f Gastroenterol 1990;7:71-8.

Grade: Ib

104 Saari A, Klvilaakso E, Inberg M, et al. Comparison of somatostatin and vasopressin in bleeding esophageal varices. Am f Gastroenterol 1990;85:804-7.

Grade: Ib

105 Rodriguez-Moreno F, Santolaria F, Glez-Reimers E, et al. A randomized trial of somatostatin vs vasopressin plus nitroglycerin in the treatment of acute vasopressin bleeding. F Hepatol 1991;13:S162 (abstract).

Grade: Ib

106 McKee R. A study of octreotide in oesophageal varices. Digestion 1990;45:60-5.

Grade: III

107 Jaramillo JL, de la Mata M, Mino G, Costan G, Gomez-Camacho F. Somatostatin versus Sengstaken balloon tamponade for primary haemostasis of bleeding esophageal varices. F Hepatol 1991;12:100-5.

08 Avgerinos A Armonis A, Manolakopoulos Grade: IIa Endoscopic sclerotherapy versus variceal ligation in the long-term management of patients with cirrhosis after long-term management of patients with cirrhosis after
variceal bleeding. A prospective randomized study. F Hepatol 1997;26:1034-41.

Grade: Ib

109 Di Febo G, Siringo S, Vacirca M, et al. Somatostatin and urgent sclerotherapy in active esophageal variceal bleeding. Gastroenterology 1990;98:A583 (abstract).

Grade: Ib

110 Jenkins SA, Copeland G, Kingsnorth A, Shields R. A prospective randomized controlled trial comparing somatostatin (SMS) and injection sclerotherapy in the control of
acute variceal haemorrhage: an interim report. Gut 1992;33:F221 (abstract).

Grade: Ib

111 Shields R, Jenkins SA, Baxter JN, et al. A prospective randomised controlled trial comparing the efficacy of somato-
statin with injection sclerotherapy in the control of bleeding statin with injection sclerotherapy in the control
oesophageal varices. $\mathcal{F}$ Hepatol 1992;16:128-37.

Grade: Ib

112 Planas R, Quer JC, Boix J, et al. A prospective randomized trial comparing somatostatin and sclerotherapy in the treatment of acute variceal bleeding. Hepatology 1994; 20:370-5.

Grade: Ib

113 Sung JJ, Chung SCS, Lai CW, Chan FKL, Leung JWC, Young MY. Octreotide infusion of emergency sclerotherapy for variceal hemorrhage. Lancet 1993;342:637-41.

Grade: Ib

114 Burroughs AK. Double blind randomised clinical trial of 5 day octreotide versus placebo associated sclerotherapy for treatment failures. Hepatology 1996;24:901 (abstract).

Grade: Ib

115 Barsoum NS, Boulous FI, Ell-Robby A, et al. Tamponade and injection sclerotherapy in the management
oesophageal varices. Br f Surg 1982;69:76-8.

16 The Copende: I Project. Sclerotherapy after first variceal hemorrhage in cirrhosis. A randomized multicenter trial. $N$ Engl $\mathcal{F} \mathrm{Med}$ 1984;311:1594-600.

Grade: Ib

117 Paquet KJ, Feusener H. Endoscopic sclerosis and esophageal balloon tamponade in acute hemorrhage from esophagogastric varices: a prospective randomised trial. Hepatology 1985;5:580-3.

Grade: Ib

118 Moreto M, Zaballa M, Bernal M, et al. A randomised trial of tamponade or sclerotherapy as immediate treatment for bleeding esophageal varices. Surg Gynecol Obstet 1988;167:331-4

119 Cello JP, Crass R, Trunkey DD. Endoscopic sclerotherapy versus esophageal transection in Child's class $C$ patients with
variceal hemorrhage. Comparison with results of portavariceal hemorrhage. Comparison with results of port
caval shunt. Preliminary report. Surgery $1982 ; 91: 333-8$. caval shunt. Preliminary report. Surgery 1982;91:333-8.
Grade: Ib

120 Huizinga WKJ, Angorn PA, Baker WW. Oesophageal transection versus injection sclerotherapy in the management of bleeding oesophageal varices in patients at high risk. Surg Gynecol Obstet 1985;160:539-46.

Grade: Ib

121 Teres J, Baroni R, Bordas JM, Vias J, Pera C, Rodes J. Randomized trial of portacaval shunt, stapling transection and endoscopic sclerotherapy in uncontrolled variceal bleeding. F Hepatol 1987;4:159-67.

Grade: Ib

122 Burroughs AK, Hamilton G, Philips A, Mezzanotte G, McIntire N, Hobbs KIEF. A comparison of sclerotherapy with staple transection of the esophagus for the emergency with staple transection of the esophagus for the emergency 1989;321:857-62.

Grade: Ib
123 Cello JP, Grendell JH, Crass RA, Weber TE, Trunkey D. Endoscopic sclerotherapy versus portacaval shunt in patients with severe cirrhosis and acute variceal hemorhage. Long term follow-up. N Engl f Med 1987;316:1115

Grade: Ib

124 Steigmann G, Goff GS. Endoscopic esophageal varix ligation: Preliminary clinical experience. Gastrointest Endosc 1988;34:113-17.

Grade: III

125 Stiegmann GV, Goff JS, MichaletzOnody PA, et al. Endoscopic sclerotherapy as compared with endoscopic ligation for bleeding esophageal varices. $N$ Engl f Med 1992;326: 1527-32.

Grade: Ib

126 Lo GH, Lai KH, Cheng JS, et al. A prospective, randomized trial of sclerotherapy versus ligation in the management of bleeding esophageal varices. Hepatology 1995;22:466-71.

Grade: Ib

127 Ramond M-J, Valla D, Mosnier J-F, et al. Successful endoscopic obturation of gastric varices with butyl cyanoacrylate. Hepatology 1989;10:488-93.

Grade: III

128 Soehendra N, Grimm H, Nam V, et al. N-Butyl-2cyanoacrylate: a supplement to endoscopic sclerotherapy. Endoscopy 1987;19:221-4.

Grade: III

129 Panes J, Teres J, Bosch J, Rodes J. Efficacy of balloon tamponade in treatment of bleeding gastric and esophageal varices. Results in 151 consecutive episodes. Dig Dis Sci 1988;33:454-9.

Grade: III

30 McCormick PA, Dick R, Panagou EB, Chin JKT, Greenslade L, Burroughs AK. Emergency transjugular intrahepatic portosystemic stent-shunt salvage treatment for uncontrolled variceal bleeding. Br f Surg 1994;81:1324-7.

Grade: III

131 Jalan R, John TG, Redhead DN, Finlayson NDC, Garden OJ, Hayes PC. A comparative study of the transjugular intrahepatic portosystemic stent-shunt (TIPSS) and oesopharahepatic portosystemic stent-shunt (TIPSS) and oesopha$\underset{f}{\text { geal transection in uncontrolled }}$ asterol 1995;11:1932-6.

Grade: IIa

132 Sanyal AJ, Freedman AM, Luketic VA, et al. Transjugular intrahepatic portosystemic stent shunts for patients with active variceal hemorrhage unresponsive to sclerotherapy. Gastroenterology 1996;111:138-46.

Grade: II

133 Rosemurgy AS, Goode SE, Zwiebel BR, et al. A prospective trial of transjugular intrahepatic portasystemic stent shunt versus small-diameter prosthetic $\mathrm{H}$-graft portacaval shunts in the treatment of bleeding varices. Ann Surg 1996;224:378-86.

Grade: Ib

134 Gatta A, Merkel C, Sacerdoti D, et al. Nadolol for prevention of variceal rebleeding in cirrhosis: a controlled clinical trial. Digestion 1987;37:22-8.

Grade: Ib

135 Queuniet AM, Czernichow P, Lerebours E, Ducrotte P, Tranvouez JL, Colin R. Etude controlée due propranolol dans la prevéntion des récidives hémorragiques chez les patients cirrhotiques. Gastroenterol Clin Biol 1987;11:41-7.

136 Sheen IS, Chen TY, Liaw YF. Randomized controlled study of propranolol for the prevention of recurrent esophageal varices bleeding in patients with cirrhosis. Liver 1989;9:1-5.

Grade: Ib

137 Rossi V, Cales P, Pascal B, et al. Prevention of recurrent variceal bleeding in alcoholic cirrhotic patients: a prospective controlled trial of propranolol and sclerotherapy. $\mathcal{F}$ Hepatol 1991;12:283-9.

Grade: Ib

138 Cerbelaud P, Lavignolle A, Perrin D, et al. Propranolol et prevention des recidives de rupture de varice oesophagienne du cirrhotique. Gastroenterol Clin Biol 1986;18:A10.

Grade: III

139 Terblanche J, Bornman PC, Kahn D, Jonker MA, Campbell JAH, Kirsch R. Failure of repeated injection sclerotherapy to improve long term survival after oesophageal variceal bleeding. A five-year prospective controlled geal variceal bleeding. A five-year p
clinical trial. Lancet 1983;2:1328-32.

140 Westaby D, MacDougall R, William R. Improved survival following sclerotherapy for esophageal varices: final analysis of a controlled trial. Hepatology 1985;5:827-30.

Grade: Ib

141 Korula J, Balart LA, Radvan G, et al. A prospective randomized controlled trial of chronic esophageal variceal sclerotherapy. Hepatology 1985;5:584-9.

Grade: Ib

142 Burroughs AK, McCormick DA, Siringo S, Phillips A, McIntyre N. Prospective randomized trial of long term sclerotherapy for variceal rebleeding, using the same proto$\mathrm{col}$ to treat rebleeding in all patients. Final report. $\mathcal{F}$ Hepatol 1989;9(suppl)S12.

Grade: Ib

143 Gregory PB. Prophylactic sclerotherapy for esophageal varices in men with alcoholic liver disease. A randomized, single-blind, multicenter clinical trial. Ann Intern Med 1991;115:73. 
144 Alexandrino PT, Martin Alves M, Pinto Correia J Propranolol or endoscopic sclerotherapy in the prevention of recurrence of variceal bleeding. A prospective, randomized clinical trial. $\mathcal{F}$ Hepatol 1988;7:175-85.

Champigneulle $B$, Patris $A$, Biga Gaucher P. Sclerotherapy endoscopique contre propranolol aprés hemorrage par rupture de varices
oesophagennes chez le cirrhotique. Gastric Enterol Clin Biol 1988;12:234-7

Grade: Ib

146 Westaby D, Polson RJ, Gimson AES, Hayes PC, Hayllar K, Williams R. A controlled trial of oral propranolol compared with injection sclerotherapy for the long-term management with injection sclerotherapy for the long-term m
of variceal bleeding. Hepatology 1990;11:353-9.

7 Grade: Ib Martin T, Taupignon A, Lavignolle A, Perrin D, LeBodic L. Prévention des récidives hémorragiques chez des malades atteints de cirrhose. Résultats d'une étude controlé comparant propranolol et sclérose endoscopique. Gastroenterol Clin Biol 1991;15:833-7.

Grade: Ib

148 Dasarathy S, Dwivedi M, Bhargava DK, Sundaram KR, Ramachandran K. A prospective randomized trial comparing repeated endoscopic sclerotherapy and propranolol in decompensated (Child class B and C) cirrhotic patients. Hepatology 1992;16:89-94.

149 Liu JD, Jeng YS, Chen PH, Siauw CP, Ko FT, Lin KY. Endoscopic injection sclerotherapy and propranolol in the
prevention of recurrent variceal bleeding. 1990 Gastroenterprevention of recurrent variceal bleeding. 19
ology World Congress Abstract Book; GP 1181.

Grade: IIa

150 Teres J, Bosch J, Garcia Pagan JC, Feu F, Cirera I, Rodes J. Propranolol vs sclerotherapy in the prevention of variceal rebleeding: a randomised controlled trial. Gastroenterology 1993;105:1508-14

Grade: Ib

151 Gimson AES, Ramage JK, Panos MZ, et al. Randomised trial of variceal banding ligation versus injection sclerotherapy for bleeding oesophageal varices. Lancet 1993;342: 391-4.

Grade: Ib

152 Laine L, El-Newihi HM, Migikovsky B, Sloane R, Garcia F. Endoscopic ligation compared with sclerotherapy for the treatment of bleeding esophageal varices. Ann Intern Med 1993;119:1-7.

Grade: Ib

153 Hou MC, Lin HC, Kuo BIT, Chen CH, Lee FY, Lee SD. Comparison of endoscopic variceal injection sclerotherapy and ligation for the treatment of esophageal variceal hemorrhage: A prospective randomized trial. Hepatology 1995;21:1517-22.

Grade: Ib

154 Hashizume $M$, Ohta $M$, Ueno $K$, Tanoue K, Kitano S, Sugimachi K. Endoscopic ligation of oesophageal varices compared with injection sclerotherapy: A prospective compared with injection sclerotherapy: A prosp
randomised trial. Gastrointest Endosc 1993;39:123-6. randomised trial. Gastrointest Endosc 1993;39:123-6.
Grade: Ib

155 Laine L. Ligation: Endoscopic treatment of choice for patients with bleeding oesophageal varices. Hepatology 1995;22:661-5.

Grade: IV

156 Rossle M, Deibert P, Haag K, et al. Randomised trial of transjugular-intrahepatic-portosystemic shunt versus endoscopy plus propranolol for prevention of variceal rebleeding. Lancet 1997;349:1043-9.

Grade: Ib

157 Sanyal AJ, Freedman AM, Luketic VA, et al. Transjugular intrahepatic portosystemic shunts compared with endoscopic sclerotherapy for the prevention of recurrent variceal hemorrhage: A randomized, controlled trial. Ann Intern Med 1997;126:849-57.

Grade: Ib

158 Cello JP, Ring EJ, Olcott EW, et al. Endoscopic sclerotherapy compared with percutaneous transjugular intrahepatic portosystemic shunt after initial sclerotherapy in patients with acute variceal hemorrhage: A randomized, controlled trial. Ann Intern Med 1997;126:858-65.

Grade: Ib

159 Cabrera J, Maynar M, Granados R, et al. Transjugular intrahepatic portosystemic shunt (TIPS) versus sclerotherapy in the elective treatment of variceal haemorrhage. Gastroenterology 1996;110:832-9.

Grade: Ib

160 Sauer P, Theilmann L, Stremmel W, Benz C, Richter GM, Stiehl A. Transjugular intrahepatic portosystemic stent shunt versus sclerotherapy plus propranolol for variceal rebleeding. Gastroenterology 1997;113:1623-31.

Grade: Ib

161 Merli M, Salerno F, Riggio O, et al. Transjugular intrahepatic portosystemic shunt versus endoscopic sclerotherapy for the prevention of variceal bleeding in cirrhosis: a randomised multicenter trial. Gruppo 53.

Grade: Ib

162 Garcia-Villareal L, Martinez-Lagares F, Sierra A, et al. Transjugular intrahepatic portosystemic shunt versus Transjugular intrahepatic portosystemic shunt versus
endoscopic sclerotherapy for the prevention of variceal rebleeding after recent variceal hemorrhage. Hepatology 1999;29:27-32.

Grade: Ib
163 Jalan R, Forrest EH, Stanley AJ, et al. A randomised trial comparing transjugular intrahepatic portosystemic stenthunt with variceal band ligation in the prevention of rebleeding from oesophageal varices. Hepatology 1997;26: 1115-22.

Grade: Ib

164 Garcia-Villareal L, Martinez-Lagares F, Sierra A, et al. TIPS vs sclerotherapy for the prevention of variceal rebleeding. Preliminary results of a randomised study. Hepatology 1996;24:208A (abstract).

Grade: Ib

164a Papatheodoridis GV, Goulis J, Leandro G, et al. Tansjugular intrahepatic protosystemic shunt compared with endoscopic treatment for prevention of variceal with endoscopic treatment for preve
rebleeding. Hepatology 1999;30:612-22.

164b Russo MW, Zacks SL, Sandler RS, Brown RS jr. Cost-effectiveness analysis of transjugular intraheptic portosystemic shunt (TIPS) versus endoscopic therapy for prevention of esophageal variceal bleeding. Hepatology 2000:31:358-63.

165 Jackson FC, Perrin EB, Felix RW, Smith AG. A clinical investigation of the portacaval shunt: survival analysis of the therapeutica operation. Ann Surg 1971;174:672-701.

Grade: III

166 Resnick RH, Iber FL, Ishiara A, Chalmers TC, Zimmermann H, The Boston Inter-Hospital Liver Group. A controlled study of the therapeutic portacaval shunt. Gastroenterology 1974;67:843-57.

Grade: Ib

167 Rueff B, Prandi D, Sicot J, et al. A controlled study of therapeutic portacaval shunt in alcoholic cirrhosis. Lancet 1976;2:655-9.

Grade: Ib

168 Reynolds TB, Donovan AJ, Mikkelsen WP, Redeker AJ, Turril FL, Weiner JM. Results of a 12 year randomized trial of portacaval shunt in patients with alcoholic liver disease of portacaval shunt in patients with alcoholic liver disease

Grade: Ib

169 Reichle FA, Fahmy WF, Golsorkhi M. Prospective comparative clinical trial with distal splenorenal and mesocaval shunts. Am f Surg 1979;137:13-21.

Grade: Ib

170 Fisher JE, Bower RH, Atanian S, Welling R. Comparison of distal and proximal splenorenal shunts. Ann Surg 1981; 194:531-44.

Grade: IIa

171 Langer B, Taylor R, Mackenzie DR. Further report of prospective randomized trial comparing distale splenorenal shunt with end-to-side portacaval shunt. Gastroenterology 1985;88:424-9.

Grade: Ib

172 Millikan WJ, Warren WD, Henderson JM, et al. The Emory prospective randomized trial: selective versus non-selective shunt to control variceal bleeding. Ann Surg 1985;201:712-21.

Grade: Ib

173 Harley HAJ, Moergan T, Redeker AG, et al. Results of a randomized trial of end-to-side portacaval shunt and distal splenorenal shunt in alcoholic liver disease and variceal bleeding. Gastroenterology 1986;91:802-9.

Grade: Ib

174 Grace ND, Conn HO, Resnick RH, et al. Distal splenorenal vs portal-systemic shunts after hemorrhage from varices: a randomized controlled trial. Hepatology 1988;8: 1475-81.

Grade: Ib

175 Rikkers LF, Burnett DA, Valentine GD, Buchi KN, Cormier RA. Shunt surgery versus endoscopic sclerotherapy for long term treatment of variceal bleeding. Early results of a randomized trial. Ann Surg 1987;206:261-9.

Grade: Ib

176 Teres J, Bordas JM, Bravo D, et al. Sclerotherapy vs distal splenorenal shunt in the elective treatment of variceal haemorrhage: a randomized controlled trial. Hepatology 1987;7:430-6.

Grade: Ib

177 Henderson JM, Kutner MH, Millikan WJ, et al. Endoscopic variceal sclerosis compared with distal splenorenal shunt to prevent recurrent variceal bleeding in cirrhosis. A prospective randomized controlled trial. Ann Intern Med 1990;112:262-9.

Grade: Ib

178 Spina GP, Santambrogio R, Opocher E, et al. Distal splenorenal shunt versus endoscopic sclerotherapy in the prevention of variceal rebleeding. First stage of a randomized, controlled trial. Ann Surg 1990;211:178-86.

Grade: Ib

179 Korula J, Yellin A, Yamada S, Weiner J, Cohen H, Reynolds TB. A prospective randomized controlled comparison of chronic endoscopic variceal sclerotherapy and portalsystemic shunt for variceal hemorrhage in Child Class A cirrhotics. Hepatology 1988;8:1242 (abstract)

Grade: Ib

180 Planas R, Boix J, Broggi M, et al. Portacaval shunt versus endoscopic sclerotherapy in the elective treatment of variceal hemorrhage. Gastroenterology 1991;100:1078-86.

181 Sarin SK, Lahoti D, Saxena SP, Murthy NS, Makwan UK. Prevalence, classification and natural history of gastric
varices: a long-term follow-up study in 568 portal varices: a long-term follow-up study in 568
hypertension patients. Hepatology 1992;16:1343-9.

Grade: III 
182 Merican I, Burroughs AK. Gastric varices. Eur $\mathcal{F}$ Gastroenterol Hepatol 1992;4:511-20.

Grade: IV

183 Gimson AES, Westaby D, Williams R. Endoscopic sclerotherapy in the management of gastric variceal haemorrhage. F Hepatol 1991;13:274-8.

Grade: IIa

184 Sarin SK. Long-term follow-up of gastric variceal sclerotherapy: an eleven year experience. Gastrointest Endosc 1997;46:8-14.

Grade: III

185 Trudeau W, Prindiville T. Endoscopic injection sclerosis in bleeding gastric varices. Gastrointest Endosc 1986;32:264-8.

186 Oho K, Iwao T, Sumino M, Toyonaga A, Tanikawa K. Ethanolamine oleate versus butyl cyanoacrylate for bleeding gastric varices: a non randomized study. Endoscopy gastric varices:

Grade: IIa

187 Williams SGJ, Peters RA, Westaby D. Thrombin-an effective treatment for gastric variceal haemorrhage. Gut 1994;35:1287-9.

Grade: III

188 Minocha A, Richards RJ. Sengstaken-Blakemore tube for control of massive bleeding from gastric varices in hiata hernia. f Clin Gastroenterol 1992;14:36-8.

Grade: III

189 Harada T, Yoshida T, Shigemitsu T, Takeo Y, Tada M Okita K. Therapeutic results of endoscopic variceal ligation for acute bleeding of oesophageal and gastric varices. $\mathcal{F}$ Gastroenterol Hepatol 1997;12:331-5.

Grade: III

190 Takeuchi M, Nakai Y, Syu A, Okamoto E, Fujimoto J. Endoscopic ligation of gastric varices. Lancet 1996;348 1038.

Grade: III

191 Greig JD, Garden OJ, Anderson JR, Carter DC. Management of gastric variceal haemorrhage. Br f Surg 1990;77: $297-9$

Grade: IV

192 Riemenschneider T, Bermel RE, Hirner A. Results from devascularisation of esophago-gastric junction after recurrent bleeding of esophageal and gastric varices. Zentralb Chir 1994;119:291-7.

Grade: III

193 Thomas PG, D’Cruz A J. Distal splenorenal shunting for bleeding gastric varices. Br F Surg 1994;81:241-4.

Grade: III

194 Kanagawa H, Mima S, Kouyama H, Gotoh K, Uchida T, Okuda K. Treatment of gastric fundal varices by balloonoccluded retrograde transvenous obliteration. $\mathcal{f}$ Gastroenterol Hepatol 1996;11:51-8.

Grade: IIb

195 Koito K, Namieno T, Nagakawa T, Morita K. Balloonoccluded retrograde transvenous obliteration for gastric varices with gastrorenal and
Roentgenol 1996;167:1317-20.

Grade: IIb
196 Kuradusenge P, Rouseeau H, Vinel J-P, et al. Hemorrhage from ruptured gastric varices: treatment with transjugular intrahepatic portosystemic stent shunts. Gastroenterol Clin Biol 1993;17:431-4.

Grade: III

197 Stanley AJ, Jalan R, Ireland HM, Redhead DN, Bouchier IAD, Hayes PC. A comparison between gastric and oesophageal variceal haemorrhage treated with transjugular intrahepatic portosystemic stent shunt (TIPSS). jugular intrahepatic portosystemic stent

Grade: IIa

98 Bleichner G, Boulanger R, Squara P, et al. Frequency of infections in cirrhotic patients presenting with acute gastrointestinal haemorrhage. Br F Surg 1986;73:724-6.

199 Pauwels A, Chami N, Guivarch P, et al. Facteurs prédictifs des infections survenant au décours des hémorragies digestives hautes (HDH) du cirrhotique (abstract). Gastroenterol Clin Biol 1990;14:A219.

200 Bernard B, Cadranel JF, Valla D, et al. Prognostic significance of bacterial infection in bleeding cirrhotic patients: a propective study. Gastroenteology 1995;108: $1828-34$.

201 Goulis J, Armonis A, Patch D, et al. Bacterial infection is independently associated with failure to control bleeding in cirrhotic patients with gastrointestinal hemorrhage. Hepatology 1998;27:1207-12.

202 Rimola A, Bory F, Teres J, et al. Oral, nonabsorbable antibiotics prevent infection in cirrhotics with gastrointestinal hemorrhage. Hepatology 1985;5:463-7.

203 Soriano G, Guarner C, Tomas A, et al. Norfloxacin prevents bacterial infection in cirrhotics with gastrointestinal haemorrhage. Gastroenterology 1992;103:126772 .

204 Blaise M, Pateron D, Trinchet JC P, et al. Systemic antibiotic therapy prevents bacterial infections in cirrhotic patients with gastrointestinal hemorrhage. Hepatology 1994;20:34-8.

205 Pauwels A, Mostefa-Kara N, Debenes B, Degoutte E, Florent C, Levy VG. Antimicrobial prophylaxis after gastrointestinal hemorrhage for cirrhotic patients with a high risk of infection. Hepatology 1996;24:802-6.

206 Hsieh WJ, Lin HC, Hwang SJ, et al. The effect of ciprofloxacin in the preventions of bacterial infection in patients with cirrhosis after upper gastrointestinal bleeding. Am $\mathcal{7}$ Gastroenterol 1998;93:962-6.

207 Zacharof AK, Petrogiannopoulos C, Flevaris C, Deliousis A, Poulikakos J. Ciprofloxacin prevents bacterial infection in cirrhotics with gastrointestinal hemorrhage (abstract). $\mathcal{F}$ Hepatol 1997;26(suppl 1):101.

208 Bernard B, Grangé J, Khac EN, Amiot X, Opolon P, Poynard T. Antibiotic prophylaxis for the prevention of bacterial infections in cirrhotic patients with gastrointestinal bleeding: A meta-analysis. Hepatology 1999;29: 1655-61. 